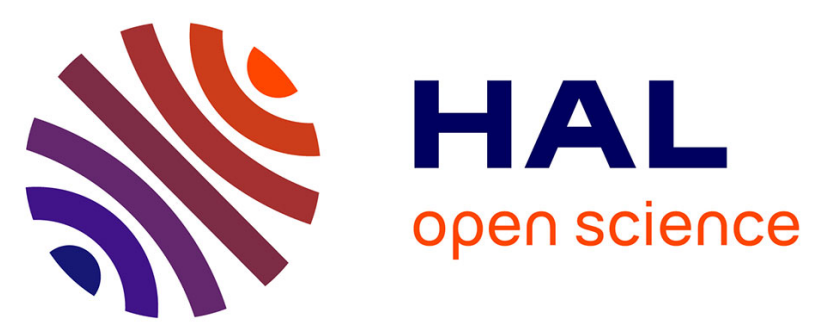

\title{
The 4 per 1000 goal and soil carbon storage under agroforestry and conservation agriculture systems in sub-Saharan Africa
}

Marc Corbeels, Rémi Cardinael, Krishna Naudin, Hervé Guibert, Emmanuel

Torquebiau

\section{To cite this version:}

Marc Corbeels, Rémi Cardinael, Krishna Naudin, Hervé Guibert, Emmanuel Torquebiau. The 4 per 1000 goal and soil carbon storage under agroforestry and conservation agriculture systems in subSaharan Africa. Soil and Tillage Research, 2019, 188, pp.16-26. hal-02022694

\section{HAL Id: hal-02022694 \\ https://hal.science/hal-02022694}

Submitted on 18 Feb 2019

HAL is a multi-disciplinary open access archive for the deposit and dissemination of scientific research documents, whether they are published or not. The documents may come from teaching and research institutions in France or abroad, or from public or private research centers.
L'archive ouverte pluridisciplinaire HAL, est destinée au dépôt et à la diffusion de documents scientifiques de niveau recherche, publiés ou non, émanant des établissements d'enseignement et de recherche français ou étrangers, des laboratoires publics ou privés. 
The 4 per 1000 goal and soil carbon storage under agroforestry and conservation agriculture systems in sub-Saharan Africa

Marc Corbeels ${ }^{1,2}$, Rémi Cardinael ${ }^{1,3}$, Krishna Naudin ${ }^{1,4}$, Hervé Guibert ${ }^{1}$, and Emmanuel Torquebiau $^{1}$

${ }^{1}$ CIRAD, UR Agro-ecology and Sustainable Intensification of Annual Crops (AIDA), University of de Montpellier, 34398 Montpellier, France

${ }^{2}$ CIMMYT, Sustainable Intensification Program (SIP), P.O. Box 1041-00621, Gigiri, Nairobi, Kenya

${ }^{3}$ University of Zimbabwe, Crop Science Department, Box MP167, Mt. Pleasant, Harare, Zimbabwe

${ }^{4}$ Embrapa Cerrados, Rodovia BR-020, Km 18, P.O. Box 08223 CEP: $73310-970$ - Planaltina DF, Brazil

* Corresponding author.

Marc Corbeels

CIMMYT c/o ICRAF House

PO Box 1041-0062, Village Market

Gigiri, Nairobi

Kenya

Tel.: +254 711999 296;

E-mail address: corbeels@ cirad.fr 


\section{Abstract}

The 4\%o initiative launched by the French government at COP21 in Paris in December 2015 aspires to increase global soil organic carbon (SOC) stocks at a rate of $0.4 \%$ per year. We conducted a systematic literature review on SOC storage under agroforestry and conservation agriculture systems in sub-Saharan Africa, where we reported 66 and 33 cases for both systems respectively. The results showed that SOC storage rates were significantly higher than $4 \% \mathrm{yr}^{-1}$ in fallows and in multistrata agroforestry systems ( $\mathrm{p}$-value $=0.0001$ and 0.0178 , respectively), but not in alley cropping and parklands systems. For conservation agriculture, SOC storage rates were only significantly higher than $4 \% \mathrm{yr}^{-1}(\mathrm{p}$-value $=0.0438)$ when all three principles were applied, i.e. no- or minimum tillage combined with crop residue retention and intercropping or rotation. The data showed very large variability in SOC storage rates as the result of various factors, including previous land-use history, experimental set up and approach used to determine SOC storage (diachronic versus synchronic approach), depth of soil sampling, soil type, type of cropping/agroforestry system and management, and duration of the experiment. SOC storage rates significantly decreased with time in the agroforestry systems (pvalue $=0.0328)$. However, we were unable to find significant relationships with initial SOC stocks or tree density. Given the limited published data and the high variability in results, no significant relationships were found for conservation agriculture. In conclusion, we argue that there is a potential for SOC storage in agricultural soils of sub-Saharan Africa, as illustrated by SOC gaps observed on smallholder farms. Low SOC levels are to a great extent the result of limited resources of most smallholder farmers in sub-Saharan Africa. Practices such as agroforestry and conservation agriculture can restore SOC in these soils, but the $4 \%$ initiative has to be implemented on the grounds of the positive impact on crop productivity rather than on climate change mitigation. The efficiency in doing so will depend on the specific situations and will need economic support to smallholder farmers, including the promotion of good 
markets for sale of extra produce and for input supply, effective private support and policy, such as credit schemes and subsidies for inputs, and efficient extension services which incentivize farmers to invest in new technologies.

Keywords: alley cropping, carbon sequestration, climate change mitigation, crop residues, crop rotation, fallows, no-tillage, parklands, intercropping 


\section{Introduction}

The Paris Climate Agreement of the United Nations Climate Conference (COP21, November 30 to December 11, 2015) commits to keeping the increase in global average temperature to well below $2{ }^{\circ} \mathrm{C}$ above pre-industrial levels and sets a more aspirational goal to limit warming to $1.5^{\circ} \mathrm{C}$. To achieve this, major greenhouse gas (GHG) reductions are needed together with technologies that result in net removal of $\mathrm{CO}_{2}$ from the atmosphere (Meinshausen et al., 2009; Field and Mach, 2017). In this context, the "4 per 1000" initiative - "Soils for Food Security and Climate" - (http://4p1000.org) was launched by the French Minister of Agriculture at the COP21, with the aspirational goal to increase soil organic carbon (SOC) stocks globally by 0.4 percent per year, suggesting that this would compensate for the global anthropogenic GHG emissions (Lal, 2016; Chabbi et al., 2017; Dignac et al., 2017; Minasny et al., 2017).

Soils store two to three times more carbon than the atmosphere, and the amount of organic carbon stored in soils is estimated at $2400 \mathrm{Gt}$ C to $2 \mathrm{~m}$ depth (Batjes, 1996). A slight increase or decrease of this SOC stock has therefore a large impact on atmospheric $\mathrm{CO}_{2}$ concentration (Schlesinger, 1977). Besides, the annual GHG emission from fossil carbon combustion is estimated at 9.3 Gt C (Le Quéré et al., 2016). The 4\%o figure simply originated from the ratio

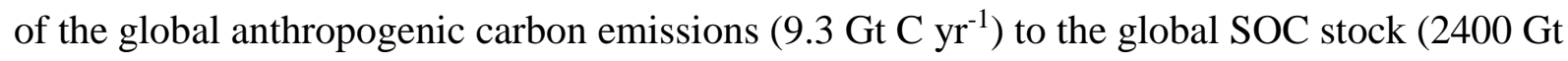
C) (Minasny et al., 2017), and thus implies that increasing global SOC stocks by 4\%o per year would completely offset the anthropogenic $\mathrm{CO}_{2}$ emissions. However, increasing SOC up to 2 $\mathrm{m}$ through changes in land management practices is rather impossible, because they are known to principally affect the topsoil SOC content (VandenBygaart, 2018). Another interpretation of the $4 \%$ figure considers therefore the global SOC stock to $40 \mathrm{~cm}$ soil depth only, arguing that a more correct scientific rationale behind the $4 \%$ initiative is to counteract the annual rise in atmospheric $\mathrm{CO}_{2}$ (de Vries, 2018). A 4\%o increase of the global 0-40 cm SOC stock, which is estimated at $860 \mathrm{Gt}$, would result in an annual sink of $3.4 \mathrm{Gt} \mathrm{C} \mathrm{yr}^{-1}$. Combining this with 
stopping deforestation (that causes an estimated emission of $0.9 \mathrm{Gt} \mathrm{C} \mathrm{yr}^{-1}$, Le Quéré et al., 2015) would lead to a net $\mathrm{CO}_{2}$ removal of $4.3 \mathrm{Gt} \mathrm{C} \mathrm{yr}^{-1}$ from the atmosphere, close to the present annual rise in atmospheric $\mathrm{CO}_{2}$, being estimated at 4.5 Gt C (Le Quéré et al., 2016).

Soil organic carbon stocks of Africa are currently estimated between 133 and $184 \mathrm{Gt}$ for the 0$100 \mathrm{~cm}$ soil layer (about $10 \%$ of the global SOC stock), with large variations depending on the ecoregion (Henry et al., 2009; Scharlemann et al., 2014). Due to an increasing demographic pressure and associated food demand, many native grassland and forest areas have been converted to croplands, and soils have experienced a massive decline in SOC, mainly as a result of low carbon inputs into soil, and topsoil erosion (Agbenin and Goladi, 1997; Solomon et al., 2002; Lemenih et al., 2005; Zingore et al., 2005; Kintché et al., 2010; Moebius-Clune et al., 2011). For example, from a review of published research it was estimated that SOC in croplands in southern Africa has declined by 25 to 53\% (Swanepoel et al., 2016). Other studies (e.g. in Western Kenya) found decreases of up to $85 \%$ of the original SOC stocks under forest (Solomon et al., 2007). These soils, far from their saturation level (Six et al., 2002; Stewart et al., 2007), are now seen as potentially important carbon sinks. The concept of SOC saturation suggests that the quantity of stable SOC in a given soil is limited since SOC stabilization, i.e. SOC protection from decomposers, is to a great extent determined by the amount of fine soil particles (typically <20 $\mu \mathrm{m}$ ) (Hassink, 1997; Six et al., 2002). The difference between the theoretical SOC saturation value and measured SOC of the fine fraction corresponds to the soil saturation deficit and may represent the potential for SOC sequestration in a stable form (Castellano et al., 2015), but this concept is now being challenged (Barré et al., 2017).

SOC increase can be achieved through the implementation of restorative land use and recommended management practices on agricultural soils (Lal, 2004). Restoring SOC levels is often seen as a win-win strategy to mitigate climate change while improving soil quality, potentially leading to higher crop yields (Lal, 2006). Important effects of increased SOC levels 
are increased supply of nutrients (Vanlauwe et al., 2005; Bationo et al., 2007), and better soil structure resulting in increased infiltration of water and reduced soil crusting, compaction and erosion (Blanco-Canqui and Lal, 2007; Nyamadzawo et al., 2007). Higher SOC levels also result in more efficient use of the agricultural inputs in cropping systems (Tittonell et al., 2008; Zingore et al., 2011). This in turn may lead to improved climate change adaptation, food security and livelihoods (Lal, 2004).

Several management practices are recognized to improve SOC contents in croplands, such as organic amendments, cover crops, improved crop rotations with or without temporal grasslands or legumes, biochar, agroforestry, or conservation agriculture (Vågen et al., 2005; Lorenz and Lal, 2014; Paustian et al., 2016).

This study focuses on the impact of agroforestry and conservation agriculture on SOC storage; both practices can increase SOC through increased carbon inputs from higher biomass productivity within a field and do not lead to carbon leakage from one field to another as often the case with recycling of exogenous organic matters (Powlson et al., 2011).

The first aim of this study is to develop evidence for increased SOC stocks under agroforestry and conservation agriculture systems in sub-Saharan Africa based on a systematic review of available data in the literature. We present the results of the review against the $4 \%$ objective and discuss the extent to which agroforestry and conservation agriculture can enhance SOC storage and contribute to climate change mitigation. Second, we highlight the opportunities and challenges that lay ahead for SOC storage in the context of African smallholder farming systems by virtue of findings from studies on soil fertility gradients on smallholder farms. Finally, we discuss the challenges with the widespread implementation of the $4 \%$ initiative in the context of African farming systems, leading to concluding commentaries on the overall findings of our study. 


\section{Materials and Methods}

\subsection{Literature search}

Using the online databases ISI Web of Science (Thomson Reuters, New York, NY, USA) and Scopus (Elsevier, Amsterdam, the Netherlands), a comprehensive search was conducted in May 2017 for peer-reviewed publications that reported SOC storage under agroforestry and conservation agriculture systems in sub-Saharan Africa (excluding South Africa). The literature search was conducted using the terms described in Table S1 (Supplementary Materials). Agroforestry is defined as the intentional, integrated combination of trees (including shrubs) and agricultural crops simultaneously or sequentially grown on the same piece of land (Nair, 1993; Torquebiau, 2000). Simultaneous systems include scattered trees in cropland, often referred to as 'parklands', alley cropping, intercropping and multistrata agroforestry. Sequential systems include improved fallows, relay cropping with trees and rotational woodlot systems where a piece of land is deliberately planted with fast-growing, often nitrogen-fixing trees (Nair, 1985). Conservation agriculture is defined according to FAO (2015) as a cropping system characterized by three principles, namely 1) continuous minimum mechanical soil disturbance; 2) permanent organic soil cover, and 3) diversification of crop species grown in sequences and/or associations.

Retrieved publications were screened and had to meet the following defined basic selection criteria to be included in our analysis. First, studies are field experiments conducted in subSaharan Africa in which SOC measurements were done on a control treatment (i.e. a cropland without an agroforestry or conservation agriculture intervention) and on an agroforestry treatment or a (partial) conservation agriculture treatment where at least the effect of no- or minimum tillage was tested ('space for time' or synchronic approach), or on a agroforestry or conservation agriculture treatment with repeated soil sampling in time (diachronic approach). Results from chronosequence studies and studies using forests or natural ecosystems as a 
control were excluded. Second, the same crop was grown in both treatment and control. Third, studies report SOC stocks, which is the quantity of carbon per unit area expressed in $\mathrm{kg} \mathrm{C} \mathrm{m}{ }^{-2}$ or $\mathrm{kg} \mathrm{C} \mathrm{ha-1}$, or SOC stocks could be calculated from the published SOC concentration expressed as proportion of the total soil mass, and soil bulk density. Studies that reported only SOC concentrations without soil bulk density were excluded. In some cases when published data were incomplete to calculate SOC stocks, the authors of the studies were contacted for additional information. In this way, SOC stocks were retrieved from the original datasets provided by the authors for the following studies: Baumert et al. (2016), Bright et al. (2017), Paul et al. (2015) and Rimhanen et al. (2016). Fourth, the treatment duration is reported in the paper.

For each study, we calculated the absolute annual rate of change in SOC stock $\left(\mathrm{kg} \mathrm{C} \mathrm{ha}^{-1} \mathrm{yr}^{-1}\right)$ and the relative rate (i.e. to the initial or control value of the SOC stock, $\% \mathrm{yr}^{-1}$ ) to the maximum soil depth specified in each paper from the initial and final measurements (diachronic approach) or from the SOC stocks under treatment and control (synchronic approach), and the duration of the treatment. When for a study SOC storage rates could be calculated with both the diachronic and synchronic approach, we used the diachronic rate in the further analysis of data because confounding effects of spatial heterogeneity with the synchronic approach may lead to less accurate results compared to the diachronic approach (Costa Junior et al., 2013). Four studies on agroforestry systems reported SOC contents for soil depths well below $40 \mathrm{~cm}$, i.e. up to 100 or $200 \mathrm{~cm}$ soil depth. To account for these potential soil depth effects, we also calculated and analyzed SOC storage rates to a maximum soil depth of $40 \mathrm{~cm}$. If $S O C$ contents to $40 \mathrm{~cm}$ depth (or less) were reported in the above four studies, they were included in this additional analysis. If a site was sampled more than once at different points in time, we used the results of the first and last reported samplings, so to obtain the largest sampling interval. Data from the same study but reported in more than one publication were not repeated to avoid double counting; the 
publication with the most complete dataset was used. When the study investigated multiple agroforestry or conservation agriculture treatments, each treatment was considered as a single point in the analysis; when multiple controls were reported, the most representative practice for the study area was used as control, and when more than one form of tillage was assessed in a study, we selected the tillage treatment representing the greatest soil disturbance as control. When a paper presented results from single control and treatment plots (no replicates), the study was not included in the analysis.

The literature search returned 183 publications for agroforestry and 157 for conservation agriculture. With the above selection criteria, 15 and 20 publications were selected in the final dataset for agroforestry and conservation agriculture, respectively. The complete reference list and details of selected publications are given as Supplementary Material (Table S2, S3).

\subsection{Statistical analyses}

All the statistical analyses were performed using R software version 3.1.1 (R Development Core Team, 2013), at a significance level of $\leq 0.05$. Reported data concerning SOC storage rates for the different agroforestry and conservation agriculture systems presented heterogeneous variances, preventing from using classical statistical tests (Scheffé, 1959; Littell et al., 2006). We therefore used a weighted least squares regression, using the $g l s$ function from the $n l m e$ package (Galecki and Burzykowski, 2013). Each observation per subsystem $i$ (alley cropping, fallows, multistrata system, parkland; no-tillage, no-tillage + residues, no-tillage + residues + rotation/intercropping) was weighted by $\frac{1}{V_{i}}$, where $V i$ was the variance of a given subsystem. Weights were normalized so that their sum equaled the total number of observations ( $\mathrm{n}=66$ for the agroforestry, $\mathrm{n}=33$ for conservation agriculture). The lsmeans function (Lenth, 2016) was then used to test whether SOC storage rates for each sub-system were significantly different 
from $0 \% \mathrm{yr}^{-1}$ and from $4 \% \mathrm{yr}^{-1}$. To compare the different subsystems, pairwise comparisons were also performed with the lsmeans function, using the Tukey's method.

\section{Results}

\subsection{Agroforestry}

The total of 15 retrieved publications from peer-reviewed literature resulted in 68 observations with absolute changes in SOC stocks reported. For two observations (Verchot et al., 2011) the relative change of SOC stock could not be calculated since the initial or control SOC levels were not reported (Table S2). This review will concern the 66 observations. The studies were conducted in 12 countries. There were 19 observations from alley cropping and eight from intercropping systems which we regrouped in our analysis. Nineteen observations came from improved fallows, one from natural fallow and five from rotational woodlots which were combined as 'fallows'. Finally, eight observations were from multistrata systems and six from parklands. Only two publications (Raddad et al., 2006; Bright et al., 2017) presented SOC stocks measured at different time periods (diachronic approach); all other publications reported data from paired-site experiments. Since the synchronic approach allowed with the available data from Bright et al. (2017) to calculate SOC storage rates that covered a longer time span (13 years) than the diachronic approach (4 years), we considered the synchronic rates for this study in the further analysis. Maximum soil sampling depth ranged from 12 to $200 \mathrm{~cm}$ (Figure 1). A majority of the data (62\%) covered only the 20 first centimeters of soil, while $20 \%$ of the data reported a maximum sampling depth of 30 to $50 \mathrm{~cm}$. Only $14 \%$ of the observations were obtained by sampling at least down to $1 \mathrm{~m}$ depth. The time since the introduction of the agroforestry system varied from 2 to 50 years, with $70 \%$ of the observations that had trees planted less than 10 years before the final soil sampling (Figure 1). 

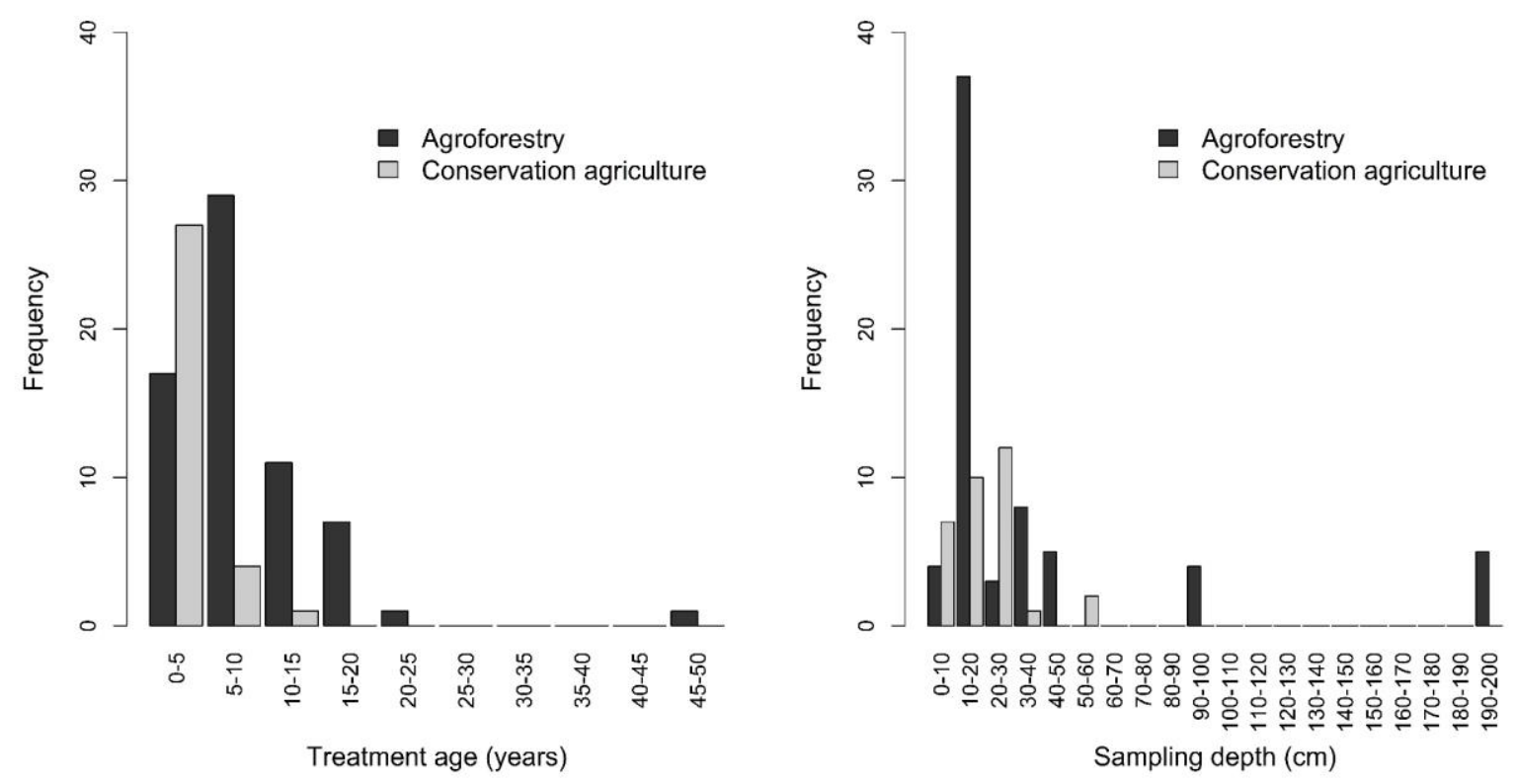

Figure 1. Number of observations for agroforestry and conservation agriculture as a function of treatment age and soil sampling depth.

Overall, the absolute rate of SOC change varied from -9.6 (0-40 cm) to $14 \mathrm{Mg} \mathrm{C} \mathrm{ha}^{-1} \mathrm{yr}^{-1}(0-$ $100 \mathrm{~cm}$ ) (Table S2). The largest rate of SOC increase was from a study with 11 years of continuous alley cropping with Maesopsis eminii Engl. on a sandy loam soil in Uganda (Tumwebaze et al., 2011). The largest decrease reported was on a loamy sand site in Burkina Faso under a 2-year alley cropping system with Jatropha curcas L. (Baumert et al., 2016).

Relative rates of SOC change varied widely from -159 to $+194 \% \mathrm{yr}^{-1}$ (Figure 2, values considering maximum reported soil depths). Eighty percent of the observations had annual relative SOC storage rates higher than $4 \% \mathrm{yr}^{-1}$. Fifty percent of the observations had SOC storage rates of $34 \% \mathrm{yr}^{-1}$ or higher.

The alley cropping, fallows and multistrata systems showed similar median rates of, respectively, 37, 37 and 45\% $\mathrm{yr}^{-1}$. Alley cropping systems showed the highest variability, with storage rates ranging from -159 to $149 \% \mathrm{yr}^{-1}$ (Figure 3). Most negative rates of SOC change 
were from paired-site comparisons between sorghum cropped alone and alley cropped with Jatropha curcas L. at seven sites in Burkina Faso with the age of the alley cropping system varying between two and four years (Baumert et al., 2016). Four observations of this same study showed, however, positive rates of SOC storage of between 15 and $67 \% \mathrm{yr}^{-1}$. Two negatives rates were also observed in multistrata systems in Ethiopia (Rimhanen et al., 2016). The highest rates of SOC storage under alley cropping (72-149\%o $\mathrm{yr}^{-1}$ ) were from paired-site comparisons where the soils were sampled to, respectively, $1 \mathrm{~m}$ and $2 \mathrm{~m}$ depth, i.e. the four observations reported by Tumwebaze et al. (2011) on alley cropping with four different tree species, and the two observations reported by Makumba et al. (2007) on alley cropping with Gliricidia sepium. We retrieved only one publication on multistrata systems (Rimhanen et al., 2016) that reported eight paired-site comparisons $(0-15 \mathrm{~cm}$ sampling depth) at different sites in Ethiopia. SOC storage rates under these systems ranged widely from -5 to $80 \% \mathrm{yr}^{-1}$. For parkland systems, there were six observations from two publications (Abaker et al., 2016, 5 observations; Gelaw et al., 2014, 1 observation). The SOC storage rates varied from -3 to $22 \% \mathrm{yr}^{-1}$, mainly depending on the type of grass species in the treatments.

Soil organic carbon storage rates were significantly higher than $4 \% \mathrm{yr}^{-1}$ (and $0 \% \mathrm{yr}^{-1}$ ) in the fallows and in the multistrata systems (p-value $=0.0001$ and 0.0178 , respectively) (Figure 3, values considering maximum reported soil depths). Rates in the fallows were significantly higher than in the parklands ( $\mathrm{p}$-value $=0.0003$ ). When we considered reported SOC contents to a maximum soil depth of $40 \mathrm{~cm}$ only, SOC rates in the fallows became significantly higher than in the alley cropping systems (p-value $=0.0169)($ Fig S1, Supplementary Materials). For the parkland systems, we were left with only one observation. Rates in the fallows and in the multistrata systems remained significantly higher than $4 \%$ o $\mathrm{yr}^{-1}\left(\right.$ and $0 \%$ $\left.\mathrm{yr}^{-1}\right)(\mathrm{p}$-value $=0.0001$ and 0.0144 , respectively). 

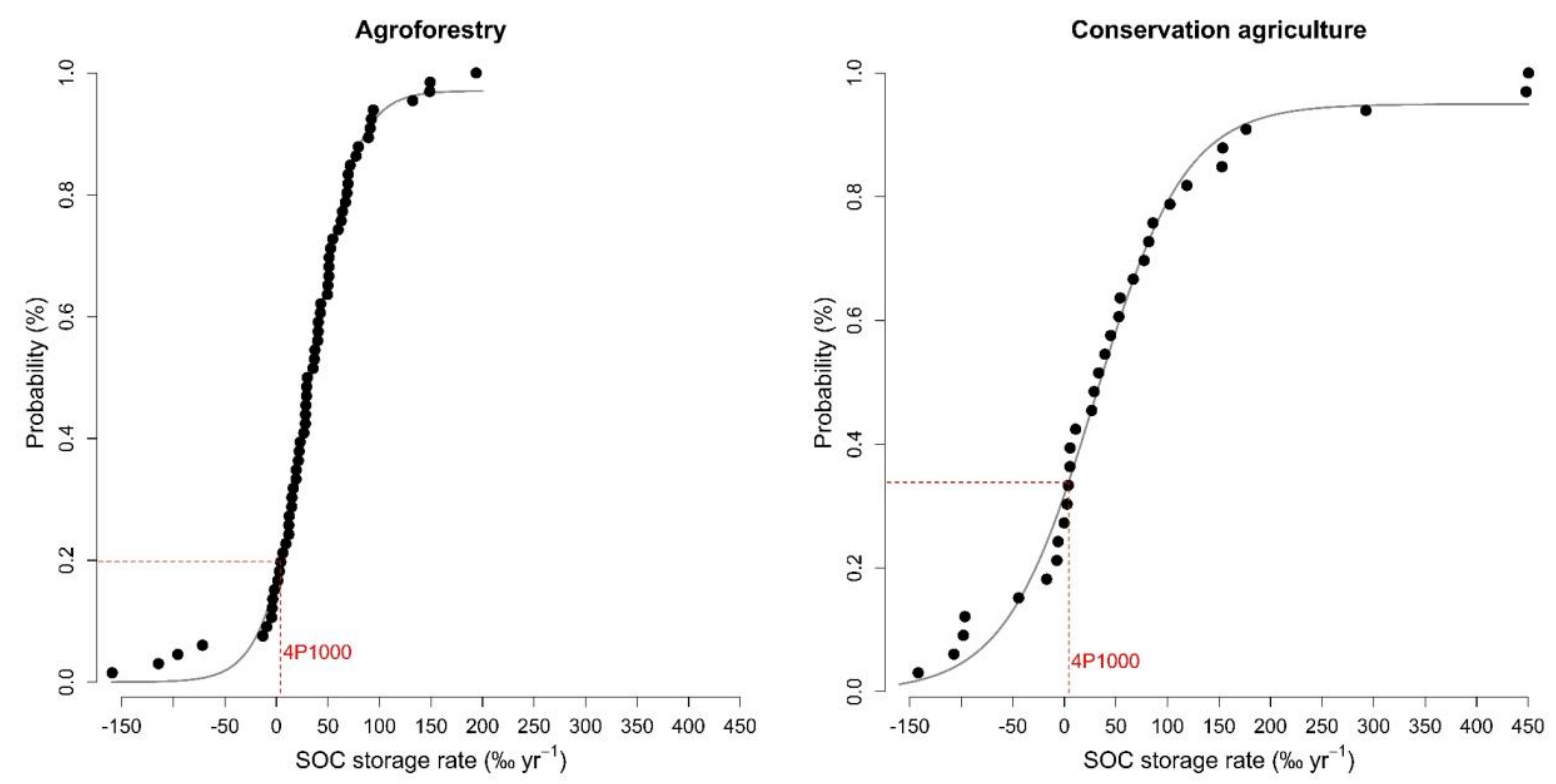

Figure 2. Cumulative distribution function of SOC storage rates in agroforestry and in conservation agriculture systems.

\subsection{Conservation agriculture}

We retrieved 20 publications that resulted in a total of 33 observations, comprising 21 sites in seven countries (Table S3). Maize was by far the most studied crop species (27 observations); the remaining studies related to six other crop species. In several studies, only one or two of the conservation agriculture principles were applied: five observations were from treatments with no-tillage alone and three observations from no- or minimum tillage with intercropping and/or rotations, but without crop residue mulching. They were grouped in the analysis (Figure 3). Ten observations were from treatments with no- or minimum tillage with crop residue mulching, but without rotation or intercropping, and 14 observations referred to treatments with all three principles of conservation agriculture applied. In one study (Ojeniyi and Adekayode, 1999), it was not clear from reading the paper whether crop residues were left on the soil or not. The one observation from this study was therefore not used when differentiating between the varying degrees of application of the conservation agriculture principles (Figure 3). Most conservation 
agriculture treatments in the dataset involved no-tillage, i.e. manual or mechanized direct seeding (26 observations). The other seven observations were minimum tillage treatments, i.e. ripping ( 5 observations) or surface scraping of the soil ( 2 observations). The tillage type to which the conservation agriculture treatment was compared was mainly ploughing (11 observations with ox-ploughing and 9 observations with tractor ploughing,). Hoeing and ridging represented respectively eight and five observations. Fourteen studies measured SOC storage through repeated sampling in time of the conservation agriculture treatment, but at the same time these studies were also paired-site comparisons between a conservation agriculture and conventional tillage treatment; the other six studies were only paired-site comparisons. Soil sampling depth ranged from 5 to $60 \mathrm{~cm}$, but $91 \%$ of the observations had a maximum sampling depth of $30 \mathrm{~cm}$ (Figure 1). The time since the introduction of the conservation agriculture treatment varied from 1 to 11 years, but $85 \%$ of the observations had a maximum treatment age of 5 years (Figure 1).

Overall, the absolute SOC change varied from $-10.2(0-30 \mathrm{~cm})$ to $6.86(0-15 \mathrm{~cm}) \mathrm{Mg} \mathrm{C}^{-1} \mathrm{yr}^{-}$ ${ }^{1}$ for observations were SOC storage was calculated using the diachronic approach (Table S3). The largest decrease reported was from a 2-year experiment on a site in south-eastern Nigeria where sweet potato was cultivated on a loam soil under no-tillage without residues retention (Anikwe and Ubochi, 2007). This large decrease can probably be explained by the fact that the site was slashed and cleared of fallow vegetation, and thus had an initial high level of relatively labile SOC that decomposed rapidly following cultivation. The data also showed large variability with least significant difference $(\mathrm{p}=0.05)$ values of up to $8.6 \mathrm{Mg} \mathrm{Cha}^{-1}$. The largest rate of SOC increase (diachronic approach) was from a study in southern Nigeria on sandy loam under 2-year no-tillage without residue retention (Agele et al., 2005), but this is probably an overestimate due to the small soil sampling depth $(0-15 \mathrm{~cm})$; the practice of no-tillage results 
in stratification of SOC concentration with depth, with surface soil layers having considerably higher SOC concentration than the layers below (Baker et al., 2007).
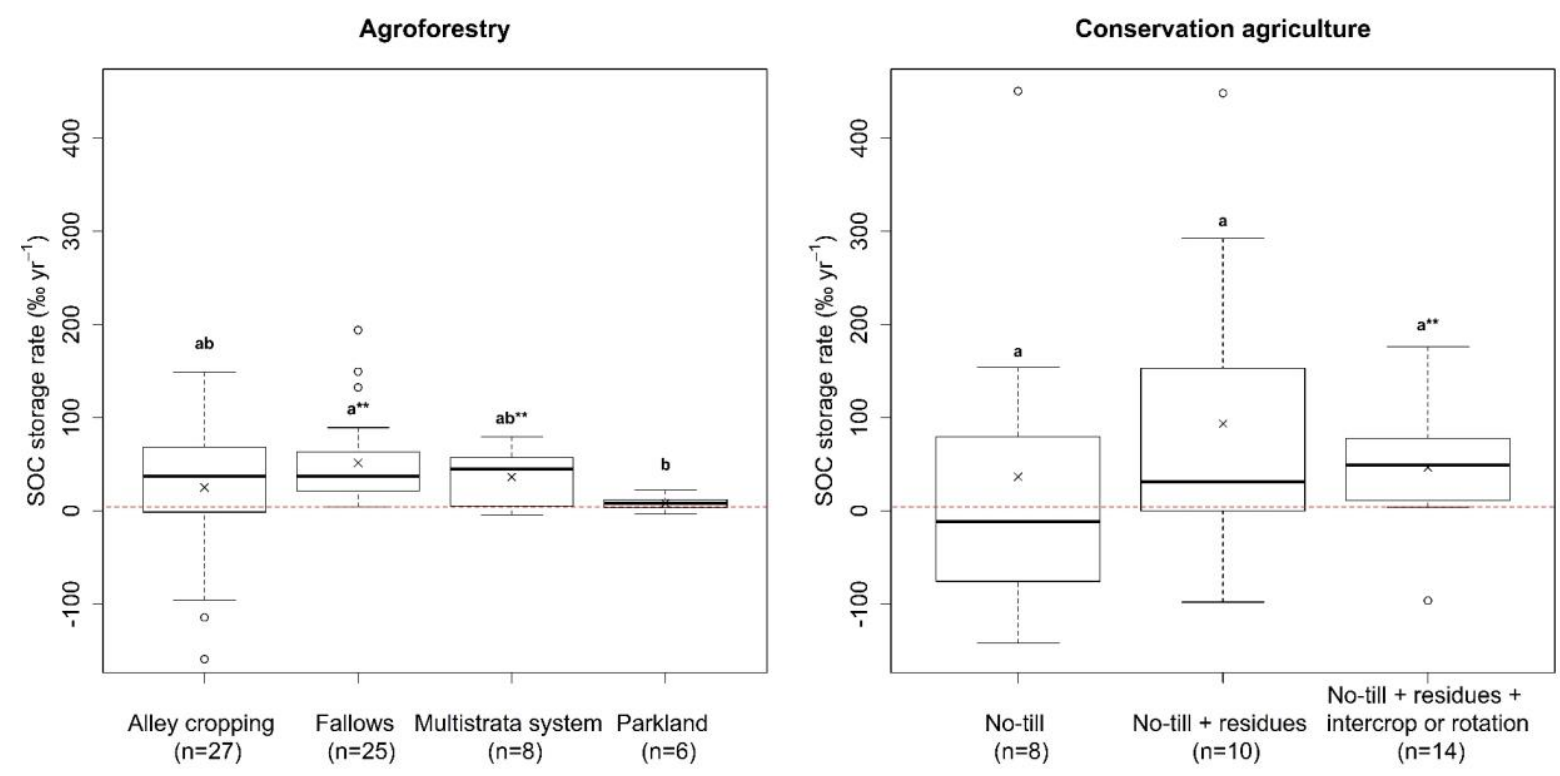

Figure 3. Soil organic carbon storage rates for different agroforestry and conservation agriculture systems. Crosses represent mean SOC storage rate per type of subsystem. For each system, different letters represent significant differences between subsystems. $* *$ represents subsystems with SOC storage rates significantly higher than $0 \% \mathrm{yr}^{-1}$ and $4 \%$ $\mathrm{yr}^{-1}$.

Relative SOC change varied from -142 to $450 \% \mathrm{yr}^{-1}$ (Figure 2). SOC change under conservation agriculture was negative for nine observations. Sixty-four percent of the studies had annual relative SOC storage rates that were higher than $4 \% \mathrm{yr}^{-1}$. Fifty percent of the observations had relative rates that were larger than $34 \%$ o $\mathrm{yr}^{-1}$. Treatments with no-tillage without residue retention showed the smallest median SOC storage rate, $-12 \%$ o $\mathrm{yr}^{-1}$ (Figure 3), and the highest variability, ranging from -142 to $450 \% \mathrm{yr}^{-1}$. The reported negative rates of SOC change were from repeated sampling on sites that were cleared from negative vegetation. They became however positive when calculated on the basis of the comparison with the conventional tillage treatment (Figure 4). Rates under no- or minimum tillage with residue retention also 
varied widely between -98 and 448\% $\mathrm{yr}^{-1}$. Again, negative rates were reported from two experiments in Nigeria where the conservation agriculture treatment was installed following clearing of native vegetation (Agbede, 2008; Lal, 1998). The highest rate (448\%o $\left.\mathrm{yr}^{-1}\right)$ was reported in a paired-site study in Malawi (Mloza-Banda et al., 2014) in which manual direct seeding with retention of crop residues was compared with ridging without crop residues on three different fields after four years. The value is an outlier and probably an overestimate. Apart from the methodological problems with making comparisons of SOC stocks between flat planting and ridge and furrow systems, the data were from three paired-site comparisons on different farmer's fields where great variability between fields is to be expected. Annual SOC rates from treatments with all three principles of conservation agriculture varied less, between -96 and $176 \% \mathrm{yr}^{-1}$ (Figure 3). The lowest rate $\left(-96 \% \mathrm{yr}^{-1}\right)$ was reported in a 2-year study in Zimbabwe by (Nyamadzawo et al., 2008) in which SOC storage was measured on a sandy clay loam $(0-20 \mathrm{~cm})$ under direct seeding of maize, following a fallow period with Sesbania sesban. The highest value of $176 \% \mathrm{yr}^{-1}$ was from a sandy loam site in Western Kenya (Ngome et al., 2011) where the soil (0-15 cm) was sampled after 1 year in a no-tillage treatment with maize grown on a permanent living cover of Arachis pintoï. Two other observations from the same study with the same conservation agriculture treatment on two different sites gave also relatively high rates of 102 (on clay) and 77\% $\mathrm{yr}^{-1}$ (on clay loam). The values were however derived from small absolute changes in measured SOC concentrations $(0.19,0.16$ and $0.15 \%$, respectively). The increase is certainly also the result of SOC redistribution nearer to the soil surface.

Only SOC storage rates in the system with the full set of conservation agriculture principles, i.e. no-tillage, residue retention and intercropping or rotation were significantly higher than $0 \%$ $\mathrm{yr}^{-1}(\mathrm{p}$-value $=0.0244)$ and $4 \% \mathrm{yr}^{-1}(\mathrm{p}$-value $=0.0438)$. SOC storage rates were not significantly 
different between the different degrees of application of the conservation agriculture principles (Figure 3).

The comparison of studies for which SOC storage rates could be calculated both using the diachronic and the synchronic approach showed that the synchronic rates were in most cases higher than $0 \% \mathrm{yr}^{-1}$ (two exceptions). They were larger than the diachronic rates, especially in case of negative diachronic rates (Figure 4). All large deviations were from conservation agriculture experiments that were installed following clearance of native vegetation or fallow. In these cases, initial SOC was relatively high, and probably labile provoking net negative changes in SOC, both for the treatment and control.

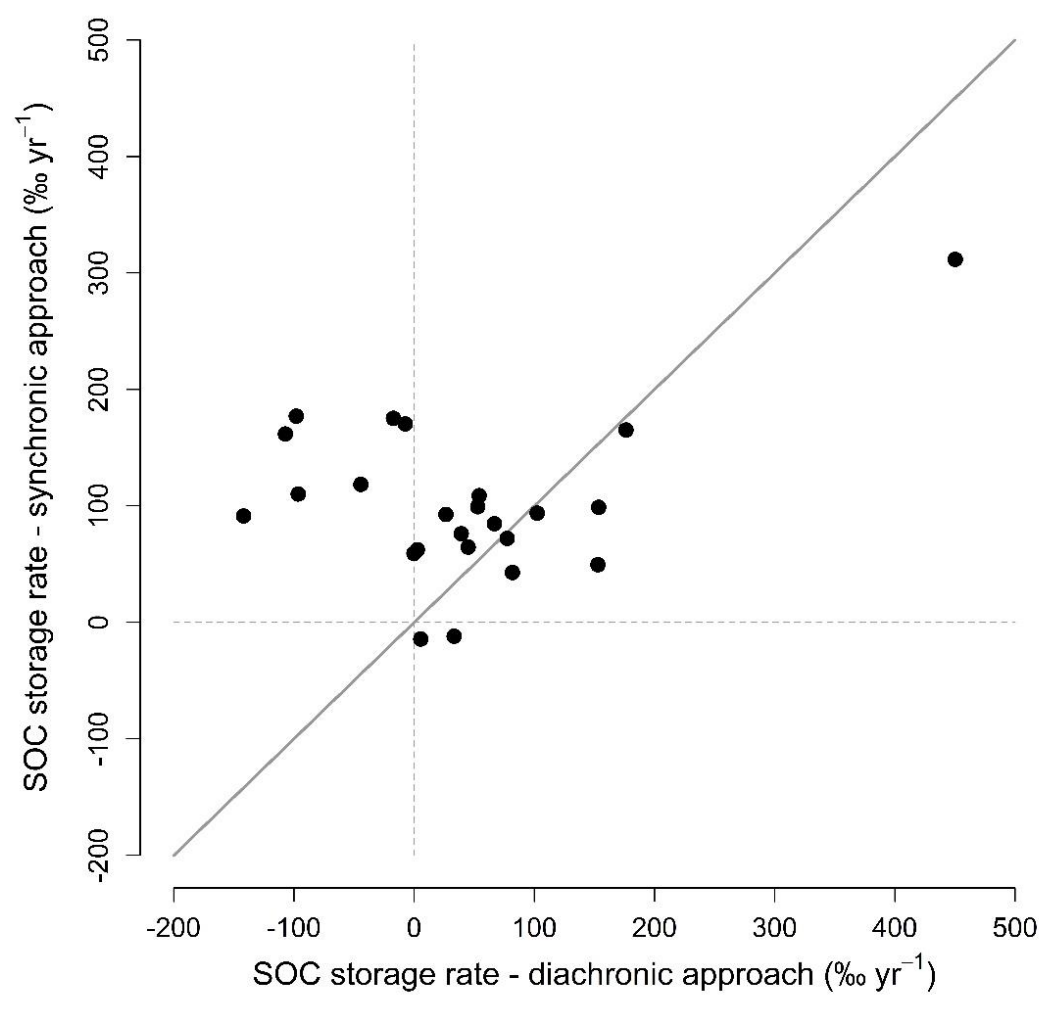

Figure 4. Comparison of SOC storage rates estimated by the diachronic or synchronic approach in conservation agriculture systems. 


\section{Discussion}

\subsection{SOC storage potentials}

Agricultural soils in sub-Saharan Africa have a strong carbon sink capacity as a result of previous SOC depletion (Lal, 2016). Theoretically, SOC stocks can be restored through soil and crop management practices that have a positive carbon budget (i.e. with carbon inputs from biomass exceeding carbon outputs through decomposition and erosion (Stockmann et al., 2013; Dignac et al., 2017)). We examined the SOC storage potentials of two widely promoted management practices in sub-Saharan Africa, agroforestry and conservation agriculture. In the following sections we discuss the extent to which these practices can increase SOC stocks and contribute to climate change mitigation. Other practices that increase carbon inputs to soil are e.g. the addition of manure or other organic materials to fields. However, adding organic materials to soil does not necessarily lead to a net transfer of carbon from the atmosphere to the soil. Depending on the alternative end use of the materials, it can just constitute a transfer from one location to another, and thus without mitigating climate change (Powlson et al., 2011).

\subsubsection{Agroforestry}

Overall, our review showed that agroforestry has a potential to store SOC (Figure 2 and 3), especially multistrata systems and fallows. The largest SOC storage rates (> 190\%o $\left.\mathrm{yr}^{-1}\right)$ were obtained with rotational woodlots (Kimaro et al., 2011). These agroforestry systems conflict however with food security goals, since edible crops are not grown in these systems. Parklands showed the lowest potential for storing SOC (Figure 3), probably because of a low tree density per hectare (Takimoto et al., 2008). Besides improving carbon levels in soils, agroforestry systems store also a vast amount of carbon in the tree aboveground and belowground biomass, which considerably increases their interest in a perspective of climate change mitigation (Luedeling et al., 2011; Zomer et al., 2016; Feliciano et al., 2018). 
Trees have an extensive root system that can grow deep into the soil (Cardinael et al., 2015b; Pierret et al., 2016) and root derived carbon is probably the most important source for SOC storage since it is more likely to be stabilized in the soil by physicochemical processes than shoot derived carbon (Balesdent and Balabane, 1996; Menichetti et al., 2015). The highest relative SOC storage rates $\left(72-149 \% \mathrm{yr}^{-1}\right)$ in our database were reported from experiments where soil was sampled to depths of 1 to $2 \mathrm{~m}$, confirming the need to sample deep soil layers to study agroforestry systems (Haile et al., 2010; Cardinael et al., 2015a). Overall, trees enhance SOC storage because of higher biomass production and carbon inputs to soil (Peichl et al., 2006; Cardinael et al., 2018) caused by increased light, water and nutrient use efficiency at the plot scale compared to monoculture. Trees can also recover nutrients from deeper soil layers and thus improve soil nutrient availability and uptake (Nair et al., 1999). Likewise, agroforestry systems with $\mathrm{N}$-fixing trees may cause higher biomass production and carbon inputs as a result of increased soil nitrogen availability (Sileshi et al., 2008). Effects of agroforestry systems on rates of SOC decomposition are far less understood (Lorenz and Lal, 2014). Changes in litter quality and in the soil microbial and faunal communities involved in SOC decomposition may play a role (Gnankambary et al., 2008; Mitchell et al., 2010).

Within a type of agroforestry system, published rates of SOC storage varied widely (Figure 3, Table S2). The age of the agroforestry system, tree density, initial SOC stock and soil texture are amongst the most influencing factors that determine SOC storage rates (Laganière et al., 2010) and to a certain extent explain the variability in published data. Rates of SOC change are likely to be smaller for older agroforestry systems since they are expected to gradually decrease as a new SOC equilibrium is reached (Paustian et al, 1997). This also means that a strict interpretation of the 4\% concept of increasing SOC stocks each year by a slightly larger absolute amount as SOC increases is not reasonable. A significant decrease of SOC storage rate with time was indeed found for agroforestry systems ( $\mathrm{p}$-value $=0.0328)($ Figure 5). This entails 
that the capacity for $\mathrm{SOC}$ storage is finite and net $\mathrm{CO}_{2}$ removals under a new management system are thus of limited duration (Powlson et al., 2011; Paustian et al., 2016). On the other hand, we did not find significant relationships between SOC storage rate and initial SOC stock or tree density (Figure 5), which is probably due to the fact that other factors, such as tree species, type of control treatment and soil and climatic conditions interfered. It is generally known that positive effects on SOC are more likely to occur in finer-textured soils than in sandy soils because of the presence of physical and structural protection of SOC (Torn et al., 1997), but we were not able to test for this effect due the lack of soil texture data in several of the retrieved publications.
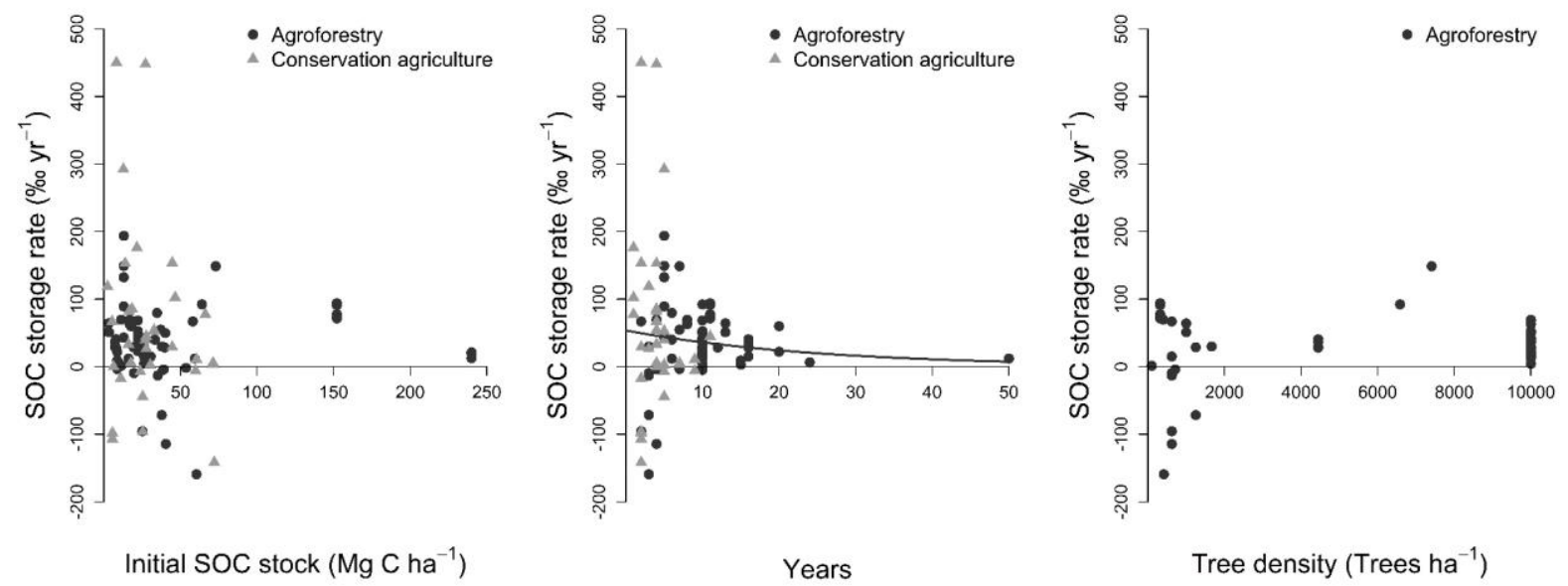

Figure 5. Soil organic carbon storage rates as a function of initial SOC stocks, age since the establishment of the studied practice, and tree density.

In conclusion, our review suggests a high potential for SOC storage under newly established agroforestry systems in soils of sub-Saharan Africa, which represents a genuine option for climate change mitigation. Most of the published values were well above the $4 \% \mathrm{yr}^{-1}$. The limited number of observations and the high variability in results ask for more research to better 
understand the positive effects of different agroforestry systems on SOC and how management could optimize these effects (Nair and Nair, 2014; Feliciano et al., 2018).

\subsubsection{Conservation agriculture}

Conservation agriculture has received much attention as a practice to increase SOC stocks and mitigate climate change (Hobbs and Govaerts, 2010; Lal, 2015). In general, SOC storage under conservation agriculture has been attributed to increased retention of crop residues compared to conventional cropping practices (Virto et al., 2012). For example, in a global meta-analysis, Luo et al. (2010) found that in most studies no-tillage alone did not increase the overall SOC stocks, except for those with increased biomass production and crop residue retention, especially via double cropping (two crops per year). These findings are corroborated by the results from our review and from a recent review by Powlson et al. (2016): no-tillage treatments with retention of crop residues and with crop rotation or intercropping resulted in the largest SOC storage rates. Moreover, we found that conservation agriculture produced SOC storage rates compatible with the " 4 per 1000 " initiative, only when all three principles are implemented (Figure 3).

No-tillage systems with retention of crop residues are also effective in reducing carbon losses through soil erosion (Ranaivoson et al., 2017). Carbon lost on a field through erosion is, however, not necessarily converted to $\mathrm{CO}_{2}$ as it may be transported and (permanently) stored in soil or sediments in another location (Wang et al., 2017).

No- or minimum tillage alone can lead to SOC storage if it decreases the rate of SOC decomposition. Six et al. (1999) showed that less disruption of macro-aggregates with no-tillage enhances the formation of micro-aggregates that are crucial in the stabilization (lower decomposition rate) and storage of SOC in the long term. The results from our review showed 
however that there was no positive effect of no-tillage on SOC storage (Figure 3). Besides, it is important to note that conversion from conventional tillage to no-tillage alters the vertical distribution of SOC in the soil profile, resulting in increased SOC in the $0-20 \mathrm{~cm}$ soil layers and decreased soil carbon in the 20-40 cm soil layers (Baker et al., 2007; Angers and EriksenHamel, 2008; Luo et al., 2010). This means that there is not necessarily a net increase in SOC stocks with no-tillage and that studies on SOC storage should investigate at least the $0-40 \mathrm{~cm}$ soil layer and not only the topsoil.

Our review showed highly variable SOC storage under conservation agriculture, with some reported rates that were anomalously large or low (Figure 2 and 3). A conclusion that was also made by Powlson et al. (2016) in their meta-analysis of SOC stock changes under conservation agriculture practices in the Indo-Gangetic Plains and SSA. We did not find significant relationships between SOC storage rate and initial SOC stock or age of the conservation agriculture systems (Figure 5). The effects of these factors may be confounded with the effects of several other factors that influence SOC storage rates. First, the agro-ecological conditions across the studies are highly heterogeneous. For example, diachronic studies that were established on a land that was cleared from natural vegetation will result in negative SOC storage rates even under conservation agriculture, whilst studies on degraded land may result in build-up of SOC. Second, various forms of conservation agriculture (and conventional tillage practices) were tested in the reported experiments. Third, several methodological approaches are used for measuring SOC storage under conservation agriculture, including diachronic versus paired-site approaches (Figure 4); on station versus on farm experiments; and different depths of soil sampling (Figure 1).

There was a major difference in SOC storage rates estimated by the diachronic versus the synchronic approach, the latter one usually leading to higher rates (Figure 4). This phenomenon can be explained by the land use history of the fields (Costa Junior et al. 2013). The diachronic 
approach provides a measure of net SOC changes under a treatment with respect to an initial state. These changes are expected to be negative under any agricultural system that was recently installed on soils that were previously under natural ecosystems (e.g. Solomon et al., 2007). In other words, diachronic rates depend to a large extent on the initial levels (and quality) of SOC, and thus on the land-use history. On the other hand, the synchronic approach compares the difference in SOC stocks of a treatment with respect to a control. Besides, spatial variability of soil properties can interfere in the synchronic approach where space is substituted for time (Costa Junior et al., 2013). As such, positive synchronic SOC rates do not provide evidence of a net SOC storage or a true carbon sink that removes $\mathrm{CO}_{2}$ from the atmosphere. This pleads for long-term diachronic experiments in sub-Saharan Africa.

In conclusion, conservation agriculture with the three principles applied can increase SOC and offer a scope for climate change mitigation, if carbon inputs are increased through higher crop productivity (intercropping and/or crop rotations). The impact will depend on the site conditions, type of cropping system, management and the historical land use. However, conservation agriculture practices, and SOC-restoration practices in general, once established, need to be preserved over time. If the practice of CA that led to increased SOC stocks is reversed, the previously accumulated $\mathrm{SOC}$ will be lost as $\mathrm{CO}_{2}$, and usually more rapidly than it was accumulated (VandenBygaart and Kay, 2004).

\subsection{Soil fertility gradients illustrate potential and challenges with SOC storage}

The potential and challenges with SOC storage in the agriculture landscapes of sub-Saharan Africa are probably best illustrated with studies on soil fertility gradients on smallholder farms (Tittonell et al., 2013). Soil fertility gradients are a consequence of the differential allocation of nutrient and labor resources to the various fields of a farm. They are the result of the limited 
resources that smallholders possess and that they tend to concentrate in the fields close to their homestead. Over time, this leads to soil fertility gradients, including gradients of SOC. Soil fertility typically decreases within a farm at increasing distances from the homestead (Prudencio, 1993; Carter and Murwira, 1995; Tittonell et al., 2005; Zingore et al., 2007). Reinforcing the soil fertility gradients, farmers often prioritize nutrient and labor allocation to their most fertile fields, where crop responses to inputs are generally highest.

For example, a case study in Western Kenya (Tittonell et al., 2008) showed gradients of SOC levels across fields in farms at three different locations (Table 1). On average per location, SOC levels in the outfields were 61,67 and $83 \%$ of those in homestead fields. The midfields had SOC levels that were 60,73 and $88 \%$ of the SOC levels in the homestead fields. These SOC gaps between fields are mainly the results of the higher use of manure or composted household waste and mineral fertilizer on the homestead fields compared to the other fields. Besides, the higher soil fertility combined with better overall management of homestead fields gave rise to higher crop yields (Table 1), which in turn results in higher carbon inputs (via roots and residues, if left on the field). These findings suggest that there is a wide scope for storing SOC in the midfields and outfields; in the presented case study between 10 to $40 \%$ of the original SOC levels. On the other hand, SOC storage on those fields is not achieved given the limited production resources of the farmers. Several authors showed that SOC storage can only be achieved with increased nutrient (most importantly, nitrogen) availability in soils (van Groenigen et al., 2006, 2017; Kirkby et al., 2013, 2014; de Vries, 2014; Richardson et al., 2014). 
Table 1: Gradients of soil organic carbon (SOC) levels $(0-30 \mathrm{~cm}$ soil layer) and maize grain yields on farmers' fields at three locations in Western Kenya (from Tittonell et al., 2008).

\begin{tabular}{lcc}
\hline Location/position within the farm & $\mathrm{SOC}\left(\mathrm{g} \mathrm{kg}^{-1}\right)$ & Grain yield $\left(\mathrm{kg} \mathrm{ha}^{-1}\right)^{\mathrm{a}}$ \\
\hline Aludeka & 10.9 & 1700 \\
Homestead field & 6.6 & 1000 \\
Midfield & 6.7 & 700 \\
Outfield & & \\
Emuhaya & 17.4 & 2400 \\
Homestead field & 12.8 & 2200 \\
Midfield & 11.7 & 1400 \\
Outfield & & \\
Shinyalu & 19.6 & 2600 \\
Homestead field & 17.2 & 1700 \\
Midfield & 16.2 & 1400 \\
Outfield & & \\
\hline
\end{tabular}

${ }^{a}$ Average maize grain yields during the 2002 long rains season

The above spatial effects of differential allocation of limited resources by farmers are also occurring at the large scale of a village, as for example illustrated in a study in north-east Zimbabwe by Zingore et al. (2011). Wealthier farmers with cattle have usually fields with higher SOC levels (especially their homestead fields) as a result of application of manure compared to poorer farmers without cattle who do not have manure. Moreover, crop residues from fields of non-cattle farmers are often grazed by cattle of the wealthier farmers, reducing the carbon inputs in the soils of these fields. As a result, fields of non-cattle owners are SOC depleted. These fields represent an important carbon sink, if farmers' resources would allow to purchase and apply organic manures, alone or in combination with chemical fertilizer. Although the higher SOC storage in the fields of the wealthier cattle-owners are to a large extent the results of a transfer of organic material from the communal grazing areas and fields of non- 
cattle farmers to their own fields, and does not constitute a net transfer of carbon from atmosphere to soil, the higher SOC levels on fields of the wealthier farmers result in higher nutrient use efficiency and crop yields, thus providing more carbon inputs to the soil, and thus a net transfer of carbon from atmosphere to soil.

\subsection{Implementation and adoption of SOC restoration practices}

Strategies for widespread adoption of SOC-restoration practices are required for the 4\%o initiative to be effective in mitigating climate change. In sub-Saharan Africa, however, the challenge to implement these strategies for agricultural soils is enormous. Many farmers are extremely poor and live below the poverty line, often with the inability to invest in new practices or technologies. It should also be clear that for smallholders, climate change mitigation is no priority (Luedeling and Neufeldt, 2012). Farmers' priorities are to get immediate benefits from farming and to ensure their food security (Jerneck and Olsson, 2014). Therefore, the entry point for promoting SOC-restoration practices should be on the grounds of increasing crop productivity through better soil quality, and not on the basis of climate change mitigation. The majority of the management practices that build SOC represent, however, "win-win'” options, and strategies to implement these practices can be promoted on a "no regrets" basis (Smith et al., 2008), i.e. they do provide other benefits even if the climate change mitigation potential is not realized. Especially in low-input smallholder farming systems, enhancing SOC storage positively impacts crop productivity (e.g. Tittonell et al., 2008), and is expected to contribute to enhanced resilience to climate change.

Despite these co-benefits, adoption of SOC-restoration practices, such as agroforestry and conservation agriculture, by smallholders is low in sub-Saharan Africa (Giller et al., 2009; Jerneck and Olsson, 2013). There are several technical, infrastructural, socio-economic, or 
policy barriers to adoption. First of all, farm sizes are small (often less than 2 ha) which raise questions about the potential impact of technological interventions on farm income (Harris and Orr, 2014). Small farm sizes make farmers also more risk averse in trying out new technologies. Second, there is a general lack of effective support for smallholder agriculture in much of subSaharan Africa, such that there are actually economic disincentives to investment in agriculture (Ehui and Pender, 2005). Private sector support is often uncertain, because only a small part of farm produce is marketed. Good markets for sale of extra produce and for input supply are a prerequisite condition for the widespread adoption of new agricultural technologies that aim at productivity increase. Third, failure of efficient extension services in most African countries limit the possibility to scale up best management practices (Davis et al., 2008). Fourth, effective policies, including input subsidies, which incentivize farmers to invest in new technologies are needed (Jayne and Rashid, 2013).

Farming systems and farmers in sub-Saharan Africa being highly diverse, a major challenge with the development and dissemination of practices such as conservation agriculture and agroforestry is the identification of situations where they can offer major benefits (Giller et al., 2011; Luedeling et al., 2011). Specific technologies should be adapted and targeted to categories of farmers who are likely to benefit from these technologies, and adapted to the local circumstances and specific farming contexts. Features that need to be considered include farmers' production objectives and constraints, expected costs (requirements in terms of inputs, equipment, labor), benefits (especially in the short term), production and financial risk, input supply and marketing, farmers' perceptions, and technical advice. This can be achieved through an innovation systems approach that fosters dynamic interactions and collaboration among researchers, extension agents, farmers, policy makers and the private sector (Schut et al., 2016). More generally, an alignment of agriculture and climate policy also appears to be essential (Chabbi et al., 2017). 


\subsection{Recommendations for SOC monitoring in field experiments}

Implementing the $4 \%$ initiative on a large scale will require the capacity to measure and monitor SOC stocks with acceptable accuracy, quantifiable uncertainty and at relatively low cost (Paustian et al., 2016). This implies the combination of direct measurements with modeling approaches (Post et al., 2001). For example, repeated measurements at a given site are needed to establish relationships between environmental and management factors and SOC dynamics to improve statistical and quantitative models as tools in monitoring, reporting and verification systems for carbon in soils (Batjes and van Wesemael, 2015). Our review clearly highlighted the scarcity of good quality data on SOC stocks under agroforestry and conservation agriculture practices in sub-Saharan Africa.

In general, there is a lack of standardized procedures for studying and reporting SOC sequestration in agroforestry and conservation agricultural systems, making it difficult to evaluate the precise effect of a given management practice. We recommend the use of the diachronic approach to estimate SOC storage rates given the high uncertainty with the synchronic approach because of spatial variability of soil properties that may influence SOC storage rates (e.g. Cerri et al., 2004). A prerequisite for interpretation of reported SOC data is information on the experimental design together with soil sampling methods (including sampling depth), sample size and a measure of variance of SOC stocks. Soil sampling depth was reported for different soil depths across the studies that we analyzed. Although the 2006 IPCC guidelines recommend a reference depth of $30 \mathrm{~cm}$, it is useful to have estimates for SOC stocks of the entire root zone or to a depth of 1 or $2 \mathrm{~m}$, especially in agroforestry systems (Cardinael et al., 2015a, 2018). Amongst other minimum data to be reported are the exact location of the experiment, climate, soil type and soil texture, soil bulk density, land-use history, date of establishment of the sequestering practice, land management practices (e.g, fertilizer 
and organic residue applications), tree density and spacing as well as the management of pruning residues in the case of agroforestry systems. Finally, an estimate of the plant productivity in the experiments is helpful for interpretation of measured SOC storage rates as it determines the carbon inputs into soil.

\section{Conclusions}

Our systematic review of published literature showed that both agroforestry and conservation agriculture have a large potential to increase SOC stocks above the rate of $4 \% \mathrm{yr}^{-1}$ in subSaharan Africa. Respectively 80 and $64 \%$ of the observations in the published studies had rates that were larger than $4 \% \mathrm{yr}^{-1}$ (Figure 2). The data showed, however, a very large variability. As a result, we found that only the agroforestry practice of fallows and multistrata systems led to SOC storage rates significantly higher than $4 \% \mathrm{yr}^{-1}$ (Figure 3). Among the agroforestry systems, parklands showed the lowest SOC storage rates, a median rate of $8 \%$ o $\mathrm{yr}^{-1}$. Only 'full' conservation agriculture, i.e. with all three principles implemented, resulted in SOC storage rates that were significantly higher than $4 \% \mathrm{yr}^{-1}$. The lowest rates were attained with no-tillage without residue retention.

The example of SOC gradients across different fields of individual farms and across farms illustrated the potential and challenges in increasing SOC stocks in the context of African smallholder agriculture. Low SOC levels are to a great extent the result of the limited resources of smallholder farmers in sub-Saharan Africa. Since climate change mitigation is not a priority for these smallholders, the $4 \%$ initiative has to be implemented on the grounds of the cobenefits that are offered through improved SOC storage. It means that for the African situation SOC-storing management practices should be promoted on the basis of their positive impact on crop productivity. Furthermore, these practices need to be targeted and adapted to the specific 
bio-physical and socio-economic situations of the farmers. The strategies to implement the $4 \%$ initiative in sub-Saharan include the promotion of good markets for sale of extra produce and for input supply, effective private support and policy, including credit schemes and subsidies for inputs, and efficient extension services which incentivize farmers to invest in new technologies.

In conclusion, we argue that there is a great potential for SOC storage in agricultural soils of sub-Saharan Africa given the large areas of SOC-depleted soils. Practices such as agroforestry and conservation agriculture have a potential to restore SOC in these soils. The efficiency in doing so will depend on the specific situations and will need economic support to smallholder farmers. Climate change mitigation should be seen as a no-regret option, not as a key driver for promoting best management options. The key driver is increased farm income through higher crop productivity.

\section{Acknowledgements}

This work was partly funded by the French Agricultural Research Centre for International Development (CIRAD) and the CGIAR Research Program MAIZE, FP 4: Sustainable Intensification of Maize-based Cropping Systems. The authors are grateful to Philippe Letourmy for his help with the statistical analysis. 


\section{References}

Abaker, W.E., Berninger, F., Saiz, G., Braojos, V., Starr, M., 2016. Contribution of Acacia senegal to biomass and soil carbon in plantations of varying age in Sudan. For. Ecol. Manage. 368, 71-80.

Agbede, T.M., 2008. Nutrient availability and cocoyam yield under different tillage practices. Soil Tillage Res. 99, 49-57.

Agbenin, J.O., Goladi, J.T., 1997. Carbon, nitrogen and phosphorus dynamics under continuous cultivation as influenced by farmyard manure and inorganic fertilizers in the savanna of northern Nigeria. Agric. Ecosyst. Environ. 63, 17-24.

Agele, S.O., Ewulo, B.S., Oyewusi, I.K., 2005. Effects of some soil management systems on soil physical properties, microbial biomass and nutrient distribution under rainfed maize production in a humid rainforest Alfisol. Nutr. Cycl. Agroecosystems 72, 121-134.

Angers, D.A., Eriksen-Hamel, N.S., 2008. Full-Inversion Tillage and Organic Carbon Distribution in Soil Profiles: A Meta-Analysis. Soil Sci. Soc. Am. J. 72, 1370.

Anikwe, M.A.N., Ubochi, J.N., 2007. Short-term changes in soil properties under tillage systems and their effect on sweet potato (Ipomea batatas L.) growth and yield in an Ultisol in south-eastern Nigeria 351-358.

Baker, J.M., Ochsner, T.E., Venterea, R.T., Griffis, T.J., 2007. Tillage and soil carbon sequestration-What do we really know? Agric. Ecosyst. Environ. 118, 1-5.

Balesdent, J., Balabane, M., 1996. Major contribution of roots to soil carbon storage inferred from maize cultivated soils. Soil Biol. Biochem. 28, 1261-1263.

Barré, P., Angers, D.A., Basile-Doelsch, I., Bispo, A., Cécillon, L., Chenu, C., Chevallier, T., Derrien, D., Eglin, T.K., Pellerin, S., 2017. Ideas and perspectives: Can we use the soil carbon saturation deficit to quantitatively assess the soil carbon storage potential, or should we explore other strategies? Biogeosciences Discuss. 1-12.

Bationo, A., Kihara, J., Vanlauwe, B., Waswa, B., Kimetu, J., 2007. Soil organic carbon dynamics, functions and management in West African agro-ecosystems. Agric. Syst. 94, $13-25$.

Batjes, N.H., 1996. Total carbon and nitrogen in the soils of the world. Eur. J. Soil Sci. 47, 151163.

Batjes, N.H., van Wesemael, B., 2015. Measuring and monitoring soil carbon, in: Banwart, S.A., Noellemeyer, E., Milne, E. (Eds.), Soil Carbon: Science, Management and Policy for Multiple Benefits. CABI, Wallingford, UK, pp. 188-201.

Baumert, S., Khamzina, A., Vlek, P.L.G., 2016. Soil Organic Carbon Sequestration in Jatropha curcas Systems in Burkina Faso. L. Degrad. Dev. 27, 1813-1819.

Blanco-Canqui, H., Lal, R., 2007. Soil structure and organic carbon relationships following 10 years of wheat straw management in no-till. Soil Tillage Res. 95, 240-254.

Bright, M.B.H., Diedhiou, I., Bayala, R., Assigbetse, K., Chapuis-Lardy, L., Ndour, Y., Dick, R.P., 2017. Long-term Piliostigma reticulatum intercropping in the Sahel: Crop productivity, carbon sequestration, nutrient cycling, and soil quality. Agric. Ecosyst. Environ. 242, 9-22. 
Cardinael, R., Chevallier, T., Barthès, B.G., Saby, N.P.., Parent, T., Dupraz, C., Bernoux, M., Chenu, C., 2015a. Impact of alley cropping agroforestry on stocks, forms and spatial distribution of soil organic carbon - A case study in a Mediterranean context. Geoderma 259-260, 288-299.

Cardinael, R., Mao, Z., Prieto, I., Stokes, A., Dupraz, C., Kim, J.H., Jourdan, C., 2015b. Competition with winter crops induces deeper rooting of walnut trees in a Mediterranean alley cropping agroforestry system. Plant Soil 391, 219-235.

Cardinael, R., Guenet, B., Chevallier, T., Dupraz, C., Cozzi, T., Chenu, C., 2018. High organic inputs explain shallow and deep SOC storage in a long-term agroforestry system Combining experimental and modeling approaches. Biogeosciences 15, 297-317.

Carter, S.E., Murwira, H.K., 1995. Spatial variability in soil fertility management and crop response in Mutoko Communal Area, Zimbabwe. Ambio 24, 77-84.

Castellano, M.J., Mueller, K.E., Olk, D.C., Sawyer, J.E., Six, J., 2015. Integrating Plant Litter Quality, Soil Organic Matter Stabilization and the Carbon Saturation Concept. Glob. Chang. Biol. 21, 3200-3209.

Cerri, C.E.P., Cerri, C.C., Paustian, K., Bernoux, M., Mellilo, J.M., 2004. Combining soil C and $\mathrm{N}$ spatial variability and modeling approaches for measuring and monitoring soil carbon sequestration. Environ. Manage. 33, 274-288.

Chabbi, A., Lehmann, J., Ciais, P., Loescher, H.W., Cotrufo, M.F., Don, A., Sanclements, M., Schipper, L., Six, J., Smith, P., Rumpel, C., 2017. Aligning agriculture and climate policy. Nat. Clim. Chang. 7, 307-309.

Costa Junior, C., Corbeels, M., Bernoux, M., Piccolo, M.C., Neto, M.S., Feigl, B.J., Cerri, C.E.P., Cerri, C.C., Scopel, E., Lal, R., 2013. Assessing soil carbon storage rates under no-tillage: Comparing the synchronic and diachronic approaches. Soil Tillage Res. 134, 207-212.

Davis, K.E., Ekboir, J., Spielman, D.J., 2008. Strengthening Agricultural Education and Training in sub-Saharan Africa from an Innovation Systems Perspective: A Case Study of Mozambique. J. Agric. Educ. Ext. 14, 35-51.

de Vries, W., 2018. Soil carbon 4 per mille: a good initiative but let's manage not only the soil but also the expectations. Geoderma 309, 111-112.

de Vries, W., 2014. Nutrients trigger carbon storage. Nat. Clim. Chang. 4, 425-427.

Dignac, M.-F., Derrien, D., Barré, P., Barot, S., Cécillon, L., Chenu, C., Chevallier, T., Freschet, G.T., Garnier, P., Guenet, B., Hedde, M., Klumpp, K., Lashermes, G., Maron, P.-A., Nunan, N., Roumet, C., Basile-Doelsch, I., 2017. Increasing soil carbon storage: mechanisms, effects of agricultural practices and proxies. A review. Agron. Sustain. Dev. $37,14$.

Ehui, S., Pender, J., 2005. Resource degradation, low agricultural productivity, and poverty in sub-Saharan Africa: Pathways out of the spiral. Agric. Econ. 32, 225-242.

Feliciano, D., Ledo, A., Hillier, J., Nayak, D.R., 2018. Which agroforestry options give the greatest soil and above ground carbon benefits in different world regions? Agric. Ecosyst. Environ. 254, 117-129.

Field, C.B., Mach, K.J., 2017. Rightsizing carbon dioxide removal. Science 356:706-707. 
Galecki, A., Burzykowski, T., 2013. Linear Mixed-Effects Models Using R: A Step-by-Step Approach. Springer Texts in Statistics.

Gelaw, A.M., Singh, B.R., Lal, R., 2014. Soil organic carbon and total nitrogen stocks under different land uses in a semi-arid watershed in Tigray, Northern Ethiopia. Agric. Ecosyst. Environ. 188, 256-263.

Giller, K.E., Tittonell, P., Rufino, M.C., van Wijk, M.T., Zingore, S., Mapfumo, P., AdjeiNsiah, S., Herrero, M., Chikowo, R., Corbeels, M., Rowe, E.C., Baijukya, F., Mwijage, A., Smith, J., Yeboah, E., van der Burg, W.J., Sanogo, O.M., Misiko, M., de Ridder, N., Karanja, S., Kaizzi, C., K'ungu, J., Mwale, M., Nwaga, D., Pacini, C., Vanlauwe, B., 2011. Communicating complexity: Integrated assessment of trade-offs concerning soil fertility management within African farming systems to support innovation and development. Agric. Syst. 104, 191-203.

Giller, K.E., Witter, E., Corbeels, M., Tittonell, P., 2009. Conservation agriculture and smallholder farming in Africa: The heretics' view. F. Crop. Res. 114, 23-34.

Gnankambary, Z., Bayala, J., Malmer, A., Nyberg, G., Hien, V., 2008. Decomposition and nutrient release from mixed plant litters of contrasting quality in an agroforestry parkland in the south-Sudanese zone of West Africa. Nutr. Cycl. Agroecosystems 82, 1-13.

Haile, S.G., Nair, V.D., Nair, P.K.R., 2010. Contribution of trees to carbon storage in soils of silvopastoral systems in Florida, USA. Glob. Chang. Biol. 16, 427-438.

Harris, D., Orr, A., 2014. Is rainfed agriculture really a pathway from poverty? Agric. Syst. 123, 84-96.

Hassink, J., 1997. The capacity of soils to preserve organic C and $\mathrm{N}$ by their association with clay and silt particles. Plant Soil 191, 77-87.

Henry, M., Valentini, R., Bernoux, M., 2009. Soil carbon stocks in ecoregions of Africa. Biogeosciences Discuss. 6, 797-823.

Hobbs, P.R., Govaerts, B., 2010. How conservation agriculture can contribute to buffering climate change, in: Reynolds, M.P. (Ed.), Climate Change and Crop Production. CAB International, pp. 177-199.

Jayne, T.S., Rashid, S., 2013. Input subsidy programs in sub-Saharan Africa: A synthesis of recent evidence. Agric. Econ. (United Kingdom) 44, 547-562.

Jerneck, A., Olsson, L., 2014. Food first! Theorising assets and actors in agroforestry: risk evaders, opportunity seekers and "the food imperative" in sub-Saharan Africa. Int. J. Agric. Sustain. 12, 1-22.

Jerneck, A., Olsson, L., 2013. More than trees! Understanding the agroforestry adoption gap in subsistence agriculture: Insights from narrative walks in Kenya. J. Rural Stud. 32, 114125.

Kimaro, A., Isaac, M., Chamshama, S., 2011. Carbon pools in tree biomass and soils under rotational woodlot systems in eastern Tanzania, in: Kumar, B., Nair, P. (Eds.), Carbon Sequestration Potential of Agroforestry Systems. Springer, pp. 142-156.

Kintché, K., Guibert, H., Sogbedji, J.M., Levêque, J., Tittonell, P., 2010. Carbon losses and primary productivity decline in savannah soils under cotton-cereal rotations in semiarid Togo. Plant Soil 336, 469-484. 
Kirkby, C.A., Richardson, A.E., Wade, L.J., Batten, G.D., Blanchard, C., Kirkegaard, J.A., 2013. Carbon-nutrient stoichiometry to increase soil carbon sequestration. Soil Biol. Biochem. 60, 77-86.

Kirkby, C.A., Richardson, A.E., Wade, L.J., Passioura, J.B., Batten, G.D., Blanchard, C., Kirkegaard, J.A., 2014. Nutrient availability limits carbon sequestration in arable soils. Soil Biol. Biochem. 68, 402-409.

Laganière, J., Angers, D.A., Paré, D., 2010. Carbon accumulation in agricultural soils after afforestation: A meta-analysis. Glob. Chang. Biol. 16, 439-453.

Lal, R., 2016. Beyond COP 21: Potential and challenges of the "4 per Thousand" initiative. J. Soil Water Conserv. 71, 20A-25A.

Lal, R., 2015. Sequestering carbon and increasing productivity by conservation agriculture. J. Soil Water Conserv. 70, 55A-62A.

Lal, R., 2006. Enhancing crop yields in the developing countries through restoration of the soil organic carbon pool in agricultural lands. L. Degrad. Dev. 17, 197-209.

Lal, R., 2004. Soil carbon sequestration impacts on global climate change and food security. Science 304, 1623-1627.

Lal, R., 1998. Soil quality changes under continuous cropping for seventeen seasons of an Alfisol in western Nigeria. L. Degrad. Dev. 9, 259-274.

Le Quéré, C., Andrew, R.M., Canadell, J.G., Sitch, S., Korsbakken, J.I., Peters, G.P., Manning, A.C., Boden, T.A., Tans, P.P., Houghton, R.A., Keeling, R.F., Alin, S., Andrews, O.D., Anthoni, P., Barbero, L., Bopp, L., Chevallier, F., Chini, L.P., Ciais, P., Currie, K., Delire, C., Doney, S.C., Friedlingstein, P., Gkritzalis, T., Harris, I., Hauck, J., Haverd, V., Hoppema, M., Klein Goldewijk, K., Jain, A.K., Kato, E., Körtzinger, A., Landschützer, P., Lefèvre, N., Lenton, A., Lienert, S., Lombardozzi, D., Melton, J.R., Metzl, N., Millero, F., Monteiro, P.M.S., Munro, D.R., Nabel, J.E.M.S., Nakaoka, S., O\&amp;apos;Brien, K., Olsen, A., Omar, A.M., Ono, T., Pierrot, D., Poulter, B., Rödenbeck, C., Salisbury, J., Schuster, U., Schwinger, J., Séférian, R., Skjelvan, I., Stocker, B.D., Sutton, A.J., Takahashi, T., Tian, H., Tilbrook, B., van der Laan-Luijkx, I.T., van der Werf, G.R., Viovy, N., Walker, A.P., Wiltshire, A.J., Zaehle, S., 2016. Global Carbon Budget 2016. Earth Syst. Sci. Data 8, 605-649.

Le Quéré, C., Peters, G.P., Andres, R.J., Andrew, R.M., Boden, T., Ciais, P., Friedlingstein, P., Houghton, R.A., Marland, G., Moriarty, R., Sitch, S., Tans, P., Arneth, A., Arvanitis, A., Bakker, D.C.E., Bopp, L., Canadell, J.G., Chini, L.P., Doney, S.C., Harper, A., Harris, I., House, J.I., Jain, A.K., Jones, S.D., Kato, E., Keeling, R.F., Klein Goldewijk, K., Körtzinger, A., Koven, C., Lefèvre, N., Omar, A., Ono, T., Park, G.-H., Pfeil, B., Poulter, B., Raupach, M.R., Regnier, P., Rödenbeck, C., Saito, S., Schwinger, J., Segschneider, J., Stocker, B.D., Tilbrook, B., van Heuven, S., Viovy, N., Wanninkhof, R., Wiltshire, A., Zaehle, S., Yue, C., 2015. Global carbon budget 2014. Earth Syst. Sci. Data 7, 45-85.

Lemenih, M., Karltun, E., Olsson, M., 2005. Soil organic matter dynamics after deforestation along a farm field chronosequence in southern highlands of Ethiopia. Agric. Ecosyst. Environ. 109, 9-19.

Lenth, R. V, 2016. Least-Squares Means: The R Package lsmeans. J. Stat. Softw. 69, 1-33.

Littell, R.C., Milliken, G.A., W, S.W., Wolfinger, R.D., Schabenberger, O., 2006. SAS for 
Mixed Models, Second Edition. SAS Institute.

Lorenz, K., Lal, R., 2014. Soil organic carbon sequestration in agroforestry systems. A review. Agron. Sustain. Dev. 34, 443-454.

Luedeling, E., Neufeldt, H., 2012. Carbon sequestration potential of parkland agroforestry in the Sahel. Clim. Change 115, 443-461.

Luedeling, E., Sileshi, G., Beedy, T., Dietz, J., 2011. Carbon Sequestration Potential of Agroforestry Systems in Africa, in: Kumar, B.M., Nair, P.K.R. (Eds.), Carbon Sequestration Potential of Agroforestry Systems. Springer, pp. 61-83.

Luo, Z., Wang, E., Sun, O.J., 2010. Can no-tillage stimulate carbon sequestration in agricultural soils? A meta-analysis of paired experiments. Agric. Ecosyst. Environ. 139, 224-231.

Makumba, W., Akinnifesi, F.K., Janssen, B., Oenema, O., 2007. Long-term impact of a gliricidia-maize intercropping system on carbon sequestration in southern Malawi. Agric. Ecosyst. Environ. 118, 237-243.

Meinshausen, M., Meinshausen, N., Hare, W., Raper, S.C.B., Frieler, K., Knutti, R., Frame, D.J., Allen, M.R., 2009. Greenhouse-gas emission targets for limiting global warming to $2{ }^{\circ} \mathrm{C}$. Nature $458,1158-1162$.

Menichetti, L., Ekblad, A., Kätterer, T., 2015. Contribution of roots and amendments to soil carbon accumulation within the soil profile in a long-term field experiment in Sweden. Agric. Ecosyst. Environ. 200, 79-87.

Minasny, B., Malone, B.P., McBratney, A.B., Angers, D.A., Arrouays, D., Chambers, A., Chaplot, V., Chen, Z.-S., Cheng, K., Das, B.S., Field, D.J., Gimona, A., Hedley, C.B., Hong, S.Y., Mandal, B., Marchant, B.P., Martin, M., McConkey, B.G., Mulder, V.L., O’Rourke, S., Richer-de-Forges, A.C., Odeh, I., Padarian, J., Paustian, K., Pan, G., Poggio, L., Savin, I., Stolbovoy, V., Stockmann, U., Sulaeman, Y., Tsui, C.-C., Vågen, T.-G., van Wesemael, B., Winowiecki, L., 2017. Soil carbon 4 per mille. Geoderma 292, 59-86.

Mitchell, R.J., Campbell, C.D., Chapman, S.J., Cameron, C.M., 2010. The ecological engineering impact of a single tree species on the soil microbial community. J. Ecol. 98, $50-61$.

Mloza-Banda, M.L., Cornelis, W.M., Mloza-Banda, H.R., Makwiza, C.N., Verbist, K., 2014. Soil properties after change to conservation agriculture from ridge tillage in sandy clay loams of mid-altitude Central Malawi. Soil Use Manag. 30, 569-578.

Moebius-Clune, B.N., van Es, H.M., Idowu, O.J., Schindelbeck, R.R., Kimetu, J.M., Ngoze, S., Lehmann, J., Kinyangi, J.M., 2011. Long-term soil quality degradation along a cultivation chronosequence in western Kenya. Agric. Ecosyst. Environ. 141, 86-99.

Nair, P.K.R., 1993. An introduction to agroforestry. Kluwer Academic Publishers, Dordrecht, The Netherlands.

Nair, P.K.R., 1985. Classification of agroforestry systems. Agrofor. Syst. 3, 97-128.

Nair, P.K.R., Buresh, R., Mugendi, D.N., Latt, C.R., 1999. Nutrient cycling in tropical agroforestry systems: myths and science, in: Buck, L.E., Lassoie, J.P., Fernandes, E.C.M. (Eds.), Agroforestry in Sustainable Agricultural Systems. CRC Press LLC, pp. 1-32.

Nair, P.K.R., Nair, V.D., 2014. Solid-fluid-gas: The state of knowledge on carbon-sequestration potential of agroforestry systems in Africa. Curr. Opin. Environ. Sustain. 6, 22-27. 
Ngome, A.F., Becker, M., Mtei, K.M., Mussgnug, F., 2011. Fertility management for maize cultivation in some soils of Western Kenya. Soil Tillage Res. 117, 69-75.

Nyamadzawo, G., Chikowo, R., Nyamugafata, P., Giller, K.E., 2007. Improved legume tree fallows and tillage effects on structural stability and infiltration rates of a kaolinitic sandy soil from central Zimbabwe. Soil Tillage Res. 96, 182-194.

Nyamadzawo, G., Chikowo, R., Nyamugafata, P., Nyamangara, J., Giller, K.E., 2008. Soil organic carbon dynamics of improved fallow-maize rotation systems under conventional and no-tillage in Central Zimbabwe. Nutr. Cycl. Agroecosystems 81, 85-93.

Ojeniyi, S.O., Adekayode, F.O., 1999. Soil conditions and cowpea and maize yield produced by tillage methods in the rainforest zone of Nigeria. Soil Tillage Res. 51, 161-164.

Paustian, K., Lehmann, J., Ogle, S., Reay, D., Robertson, G.P., Smith, P., 2016. Climate-smart soils. Nature 532, 49-57.

Peichl, M., Thevathasan, N. V, Gordon, A.M., Huss, J., Abohassan, R.A., 2006. Carbon sequestration potentials in temperate tree-based intercropping systems, southern Ontario, Canada. Agrofor. Syst. 66, 243-257.

Pierret, A., Maeght, J.-L., Clément, C., Montoroi, J.-P., Hartmann, C., Gonkhamdee, S., 2016. Understanding deep roots and their functions in ecosystems: an advocacy for more unconventional research. Ann. Bot. 118, 621-635.

Post, W.M., Izaurralde, R.C., Mann, L.K., Bliss, N., 2001. Monitoring and verifying changes of organic carbon in soil. Clim. Change 51, 73-99.

Powlson, D.S., Stirling, C.M., Thierfelder, C., White, R.P., Jat, M.L., 2016. Does conservation agriculture deliver climate change mitigation through soil carbon sequestration in tropical agro-ecosystems? Agric. Ecosyst. Environ. 220, 164-174.

Powlson, D.S., Whitmore, A.P., Goulding, K.W.T., 2011. Soil carbon sequestration to mitigate climate change: A critical re-examination to identify the true and the false. Eur. J. Soil Sci. $62,42-55$.

Prudencio, C., 1993. Ring management of soils and crops in the west African semi-arid tropics: The case of the mossi farming system in Burkina Faso. Agric. Ecosyst. Environ.

Raddad, E.Y., Luukkanen, O., Salih, A.A., Kaarakka, V., Elfadl, M.A., 2006. Productivity and nutrient cycling in young Acacia senegal farming systems on vertisol in the Blue Nile region, Sudan. Agrofor. Syst. 68, 193-207.

R Development Core Team, 2013. R: A language and environment for statistical computing.

Ranaivoson, L., Naudin, K., Ripoche, A., Affholder, F., Rabeharisoa, L., Corbeels, M., 2017. Agro-ecological functions of crop residues under conservation agriculture. Agron. Sustain. Dev. 37 (26), 1-17.

Richardson, A.E., Kirkby, C.A., Banerjee, S., Kirkegaard, J.A., 2014. The inorganic nutrient cost of building soil carbon. Carbon Manag. 5, 265-268.

Rimhanen, K., Ketoja, E., Yli-Halla, M., Kahiluoto, H., 2016. Ethiopian agriculture has greater potential for carbon sequestration than previously estimated. Glob. Chang. Biol. 22, 37393749.

Scharlemann, J.P., Tanner, E.V., Hiederer, R., Kapos, V., 2014. Global soil carbon: 
understanding and managing the largest terrestrial carbon pool. Carbon Manag. 5, 81-91.

Scheffé, H., 1959. The Analysis of Variance. John Wiley \& Sons, Inc.

Schlesinger, W.H., 1977. Carbon balance in terrestrial detritus. Annu. Rev. Ecol. Syst. 8, 5181.

Schut, M., van Asten, P., Okafor, C., Hicintuka, C., Mapatano, S., Nabahungu, N.L., Kagabo, D., Muchunguzi, P., Njukwe, E., Dontsop-Nguezet, P.M., Sartas, M., Vanlauwe, B., 2016. Sustainable intensification of agricultural systems in the Central African Highlands: The need for institutional innovation. Agric. Syst. 145, 165-176.

Sileshi, G., Akinnifesi, F.K., Ajayi, O.C., Place, F., 2008. Meta-analysis of maize yield response to woody and herbaceous legumes in sub-Saharan Africa. Plant Soil 307, 1-19.

Six, J., Conant, R.T., Paul, E.A., Paustian, K., 2002. Stabilization mechanisms of soil organic matter: Implications for C-saturation of soils. Plant Soil 241, 155-176.

Six, J., Elliott, E.T., Paustian, K., 1999. Aggregate and Soil Organic Matter Dynamics under Conventional and No-Tillage Systems. Soil Sci. 63, 1350-1358.

Smith, P., Martino, D., Cai, Z., Gwary, D., Janzen, H., Kumar, P., McCarl, B., Ogle, S., O’Mara, F., Rice, C., Scholes, B., Sirotenko, O., Howden, M., McAllister, T., Pan, G., Romanenkov, V., Schneider, U., Towprayoon, S., Wattenbach, M., Smith, J., 2008. Greenhouse gas mitigation in agriculture. Philos. Trans. R. Soc. Lond. B. Biol. Sci. 363, 789-813.

Solomon, D., Fritzsche, F., Lehmann, J., Tekalign, M., Zech, W., 2002. Soil organic matter dynamics in the subhumid agroecosystems of the Ethiopian highlands: Evidence from natural C-13 abundance and particle-size fractionation. Soil Sci. Soc. Am. J. 66, 969-978.

Solomon, D., Lehmann, J., Kinyangi, J., Amelung, W., Lobe, I., Pell, A., Riha, S., Ngoze, S., Verchot, L., Mbugua, D., Skjemstad, J., Schäfer, T., 2007. Long-term impacts of anthropogenic perturbations on dynamics and speciation of organic carbon in tropical forest and subtropical grassland ecosystems. Glob. Chang. Biol. 13, 511-530.

Stewart, C.E., Paustian, K., Conant, R.T., Plante, A.F., Six, J., 2007. Soil carbon saturation: concept, evidence and evaluation. Biogeochemistry 86, 19-31.

Stockmann, U., Adams, M. a., Crawford, J.W., Field, D.J., Henakaarchchi, N., Jenkins, M., Minasny, B., McBratney, A.B., Courcelles, V.D.R. De, Singh, K., Wheeler, I., Abbott, L., Angers, D. a., Baldock, J., Bird, M., Brookes, P.C., Chenu, C., Jastrow, J.D., Lal, R., Lehmann, J., O’Donnell, A.G., Parton, W.J., Whitehead, D., Zimmermann, M., 2013. The knowns, known unknowns and unknowns of sequestration of soil organic carbon. Agric. Ecosyst. Environ. 164, 80-99.

Swanepoel, C.M., van der Laan, M., Weepener, H.L., du Preez, C.C., Annandale, J.G., 2016. Review and meta-analysis of organic matter in cultivated soils in southern Africa. Nutr. Cycl. Agroecosystems 104, 107-123.

Tittonell, P., Muriuki, a, Klapwijk, C.J., Shepherd, K.D., Coe, R., Vanlauwe, B., 2013. Soil Heterogeneity and Soil Fertility Gradients in Smallholder Farms of the East African Highlands. Soil Sci. Soc. Am. J. 77, 525-538.

Tittonell, P., Vanlauwe, B., Corbeels, M., Giller, K.E., 2008. Yield gaps, nutrient use efficiencies and response to fertilisers by maize across heterogeneous smallholder farms 
of western Kenya. Plant Soil 313, 19-37.

Tittonell, P., Vanlauwe, B., Leffelaar, P.A., Shepherd, K.D., Giller, K.E., 2005. Exploring diversity in soil fertility management of smallholder farms in western Kenya. Agric. Ecosyst. Environ. 110, 166-184.

Torn, M.S., Trumbore, S.E., Chadwick, O.A., Vitousek, P.M., Hendricks, D.M., 1997. Mineral control of soil organic carbon storage and turnover. Nature 389, 3601-3603.

Torquebiau, E.F., 2000. A renewed perspective on agroforestry concepts and classification. Life Sci. 323, 1009-1017.

Tumwebaze, S.B., Bevilacqua, E., Briggs, R., Volk, T., 2011. Soil organic carbon under a linear simultaneous agroforestry system in Uganda. Agrofor. Syst. 84, 11-23.

Vågen, T.-G., Lal, R., Singh, B.R., 2005. Soil Carbon Sequestration in Sub-Saharan Africa: a Review. L. Degrad. Dev. 16, 53-71.

van Groenigen, J.W., van Kessel, C., Hungate, B.A., Oenema, O., Powlson, D.S., van Groenigen, K.J., 2017. Sequestering Soil Organic Carbon: A Nitrogen Dilemma. Environ. Sci. Technol. 51, 4738-4739.

van Groenigen, K.-J., Six, J., Hungate, B. A, de Graaff, M.-A., van Breemen, N., van Kessel, C., 2006. Element interactions limit soil carbon storage. PNAS 103, 6571-6574.

VandenBygaart, A.J., 2018. Comments on soil carbon 4 per mille by Minasny et al. 2017. Geoderma 309, 113-114.

VandenBygaart, A.J., Kay, B.D., 2004. Persistence of Soil Organic Carbon after Plowing a Long-Term No-Till Field in Southern Ontario, Canada. Soil Sci. Soc. Am. J. 68, 13941402.

Vanlauwe, B., Diels, J., Sanginga, N., Merckx, R., 2005. Long-term integrated soil fertility management in South-western Nigeria: Crop performance and impact on the soil fertility status. Plant Soil 273, 337-354.

Virto, I., Barré, P., Burlot, A., Chenu, C., 2012. Carbon input differences as the main factor explaining the variability in soil organic $\mathrm{C}$ storage in no-tilled compared to inversion tilled agrosystems. Biogeochemistry 108, 17-26.

Wang, Z., Hoffmann, T., Six, J., Kaplan, J.O., Govers, G., Doetterl, S., Van Oost, K., 2017. Human-induced erosion has offset one-third of carbon emissions from land cover change. Nat. Clim. Chang. 1-6.

Zingore, S., Manyame, C., Nyamugafata, P., Giller, K.E., 2005. Long-term changes in organic matter of woodland soils cleared for arable cropping in Zimbabwe. Eur. J. Soil Sci. 56, $727-736$.

Zingore, S., Murwira, H.K., Delve, R.J., Giller, K.E., 2007. Soil type, management history and current resource allocation: Three dimensions regulating variability in crop productivity on African smallholder farms. F. Crop. Res. 101, 296-305.

Zingore, S., Tittonell, P., Corbeels, M., van Wijk, M.T., Giller, K.E., 2011. Managing soil fertility diversity to enhance resource use efficiencies in smallholder farming systems: A case from Murewa District, Zimbabwe. Nutr. Cycl. Agroecosystems 90, 87-103.

Zomer, R.J., Neufeldt, H., Xu, J., Ahrends, A., Bossio, D., Trabucco, A., Noordwijk, M. Van, 
Wang, M., 2016. Global Tree Cover and Biomass Carbon on Agricultural Land: The contribution of agroforestry to global and national carbon budgets. Sci. Rep. 6, 29987. doi:10.1038/srep29987 


\section{Supplementary materials}

Table S1: Lists of terms used in the literature search using the engines ISI Web of Science and and Scopus for carrying out the literature search.

\begin{tabular}{|c|c|}
\hline Agroforestry & $\begin{array}{l}\text { soil AND ("carbon stock*" OR "carbon pool*" OR "carbon sequestration" } \\
\text { OR "carbon concentration") AND (Africa* OR Angola OR Benin OR } \\
\text { Botswana OR Burkina OR Burundi OR Cameroon OR Chad OR Congo OR } \\
\text { Ivory OR Guinea OR Eritrea OR Ethiopia OR Gabon OR Gambia OR Ghana } \\
\text { OR Kenya OR Liberia OR Madagascar OR Malawi OR Mali OR Mauritania } \\
\text { OR Mozambique OR Namibia OR Niger OR Nigeria OR Rwanda OR } \\
\text { Senegal OR "Sierra Leone" OR Somalia OR Sudan OR Tanzania OR Togo } \\
\text { OR Uganda OR Zambia OR Zimbabwe)***AND(agroforest* OR parkland* } \\
\text { OR "cereal*tree intercrop*" OR silvo*arable OR "rotation* wood*" OR } \\
\text { tree*fallow* OR (tree* AND "improve* fallow*") OR (tree* AND } \\
\text { relay*crop*) OR (tree* AND alley*crop*)) }\end{array}$ \\
\hline $\begin{array}{l}\text { Conservation } \\
\text { agriculture }\end{array}$ & $\begin{array}{l}\text { soil AND carbon AND (Africa* OR Angola OR Benin OR Botswana OR } \\
\text { Burkina OR Burundi OR Cameroon OR Chad OR Congo OR Ivory OR } \\
\text { Guinea OR Eritrea OR Ethiopia OR Gabon OR Gambia OR Ghana OR } \\
\text { Kenya OR Liberia OR Madagascar OR Malawi OR Mali OR Mauritania OR } \\
\text { Mozambique OR Namibia OR Niger OR Nigeria OR Rwanda OR Senegal } \\
\text { OR "Sierra Leone" OR Somalia OR Sudan OR Tanzania OR Togo OR } \\
\text { Uganda OR Zambia OR Zimbabwe OR Swaziland) AND ("conservation } \\
\text { agriculture" OR "zero till*" OR zero-till* OR "no till*" OR no-till* OR } \\
\text { "reduced till*" OR reduced-till* OR "minimum till*" OR minimum-till* OR } \\
\text { "direct seeding" OR "direct drill*" OR direct-drill* OR mulch*) }\end{array}$ \\
\hline
\end{tabular}


Table S2: Reference list and details of the selected publications for the analysis of SOC storage under agroforestry systems

\begin{tabular}{|c|c|c|c|c|c|c|c|c|c|c|c|}
\hline \multirow{2}{*}{$\begin{array}{l}\text { Reference } \\
\text { Baumert et al., (2016) }\end{array}$} & \multirow{2}{*}{$\begin{array}{c}\text { Country } \\
\text { Burkina Faso }\end{array}$} & \multicolumn{2}{|c|}{ Coordinates } & \multirow{2}{*}{$\begin{array}{c}\begin{array}{c}\text { Altitude } \\
\text { (masl) }\end{array} \\
- \\
\end{array}$} & \multirow{2}{*}{$\begin{array}{c}\begin{array}{c}\text { Mean annual } \\
\text { precipitation } \\
\text { (mm) }\end{array} \\
- \\
\end{array}$} & \multirow{2}{*}{$\begin{array}{c}\begin{array}{c}\text { Mean annual } \\
\text { temperature } \\
\left({ }^{\circ} \mathbf{C}\right)\end{array} \\
- \\
\end{array}$} & \multicolumn{3}{|c|}{ Sand/Silt/Clay (\%) } & \multirow{2}{*}{$\begin{array}{c}\text { Agroforestry type } \\
\text { Alley cropping } \\
\end{array}$} & \multirow{2}{*}{$\begin{array}{c}\text { Tree density } \\
\left.\text { (trees ha }^{-1}\right)\end{array}$} \\
\hline & & - & - & & & & - & - & - & & \\
\hline Baumert et al., (2016) & Burkina Faso & - & - & - & - & - & - & - & - & Alley cropping & 625 \\
\hline Baumert et al., (2016) & Burkina Faso & - & - & - & - & - & - & - & - & Alley cropping & 625 \\
\hline Baumert et al., (2016) & Burkina Faso & - & - & - & - & - & - & - & - & Alley cropping & 625 \\
\hline Baumert et al., (2016) & Burkina Faso & - & - & - & - & - & - & - & - & Alley cropping & 625 \\
\hline Baumert et al., (2016) & Burkina Faso & - & - & - & - & - & - & - & - & Alley cropping & 714 \\
\hline Baumert et al., (2016) & Burkina Faso & - & - & - & - & - & - & - & - & Alley cropping & 625 \\
\hline Baumert et al., (2016) & Burkina Faso & - & - & - & - & - & - & - & - & Alley cropping & 1667 \\
\hline Baumert et al., (2016) & Burkina Faso & - & - & - & - & - & - & - & - & Alley cropping & 1250 \\
\hline Baumert et al., (2016) & Burkina Faso & - & - & - & - & - & - & - & - & Alley cropping & 1250 \\
\hline Baumert et al., (2016) & Burkina Faso & - & - & - & - & - & - & - & - & Alley cropping & 417 \\
\hline Gelaw et al., (2014) & Ethiopia & $15^{\circ} 29^{\prime} \mathrm{N}$ & $55^{\circ} 30^{\prime} \mathrm{E}$ & 1980 & 558 & - & - & - & - & Parkland & - \\
\hline Rimhanen et al., (2016) & Ethiopia & - & - & 1895 & - & - & - & - & - & Multistrata system & - \\
\hline Rimhanen et al., (2016) & Ethiopia & - & - & 1895 & - & - & - & - & - & Multistrata system & - \\
\hline Rimhanen et al., (2016) & Ethiopia & - & - & 1871 & - & - & - & - & - & Multistrata system & - \\
\hline Rimhanen et al., (2016) & Ethiopia & - & - & 1970 & - & - & - & - & - & Multistrata system & - \\
\hline Rimhanen et al., (2016) & Ethiopia & - & - & 2025 & - & - & - & - & - & Multistrata system & - \\
\hline Rimhanen et al., (2016) & Ethiopia & - & - & 2050 & - & - & - & - & - & Multistrata system & - \\
\hline Rimhanen et al., (2016) & Ethiopia & - & - & 2040 & - & - & - & - & - & Multistrata system & - \\
\hline Rimhanen et al., (2016) & Ethiopia & - & - & 2031 & - & - & - & - & - & Multistrata system & - \\
\hline Verchot et al., (2011) & Kenya & $0^{\circ} 6^{\prime} \mathrm{N}$ & $34^{\circ} 29^{\prime} \mathrm{E}$ & 1450 & $1500-1800$ & $22-24$ & - & - & - & Improved fallow & - \\
\hline Verchot et al., (2011) & Kenya & $0^{\circ} 38^{\prime} \mathrm{N}$ & $34^{\circ} 15^{\prime} \mathrm{E}$ & 1153 & $1500-1800$ & $22-24$ & - & - & - & Improved fallow & - \\
\hline Makumba et al., (2007) & Malawi & $15^{\circ} 30^{\prime} \mathrm{S}$ & $35^{\circ} 15^{\prime} \mathrm{E}$ & 1029 & 930 & - & 46 & 12 & 42 & Intercropping & 6584 \\
\hline Makumba et al., (2007) & Malawi & $15^{\circ} 30^{\prime} \mathrm{S}$ & $35^{\circ} 15^{\prime} \mathrm{E}$ & 1029 & 930 & - & 46 & 12 & 42 & Intercropping & 6584 \\
\hline
\end{tabular}




\begin{tabular}{|c|c|c|c|c|c|c|c|c|c|c|c|}
\hline Makumba et al., (2007) & Malawi & $15^{\circ} 30^{\prime} \mathrm{S}$ & $35^{\circ} 15^{\prime} \mathrm{E}$ & 1029 & 930 & - & 46 & 12 & 42 & Intercropping & 6584 \\
\hline Makumba et al., (2007) & Malawi & $15^{\circ} 30^{\prime} \mathrm{S}$ & $35^{\circ} 15^{\prime} \mathrm{E}$ & 1029 & 930 & - & 46 & 12 & 42 & Intercropping & 6584 \\
\hline Diels et al., (2004) & Nigeria & $7^{\circ} 30^{\prime} \mathrm{N}$ & $3^{\circ} 54^{\prime} \mathrm{E}$ & - & 1278 & 26 & - & - & - & Alley cropping & 4444 \\
\hline Diels et al., (2004) & Nigeria & $7^{\circ} 30^{\prime} \mathrm{N}$ & $3^{\circ} 54^{\prime} \mathrm{E}$ & - & 1278 & 26 & - & - & - & Alley cropping & 4444 \\
\hline Diels et al., (2004) & Nigeria & $7^{\circ} 30^{\prime} \mathrm{N}$ & $3^{\circ} 54^{\prime} \mathrm{E}$ & - & 1278 & 26 & - & - & - & Alley cropping & 4444 \\
\hline Diels et al., (2004) & Nigeria & $7^{\circ} 30^{\prime} \mathrm{N}$ & $3^{\circ} 54^{\prime} \mathrm{E}$ & - & 1278 & 26 & - & - & - & Alley cropping & 4444 \\
\hline Bright et al., (2017) & Senegal & $13^{\circ} 45^{\prime} \mathrm{N}$ & $15^{\circ} 47^{\prime} \mathrm{W}$ & 18 & 709 & - & 90 & - & - & Intercropping & 1000 \\
\hline Bright et al., (2017) & Senegal & $13^{\circ} 45^{\prime} \mathrm{N}$ & $15^{\circ} 47^{\prime} \mathrm{W}$ & 18 & 709 & - & 90 & - & - & Intercropping & 1000 \\
\hline Bright et al., (2017) & Senegal & $13^{\circ} 45^{\prime} \mathrm{N}$ & $15^{\circ} 47^{\prime} \mathrm{W}$ & 18 & 709 & - & 90 & - & - & Intercropping & 1000 \\
\hline Bright et al., (2017) & Senegal & $13^{\circ} 45^{\prime} \mathrm{N}$ & $15^{\circ} 47^{\prime} \mathrm{W}$ & 18 & 709 & - & 90 & - & - & Intercropping & 1000 \\
\hline Raddad et al., (2006) & Sudan & $34^{\circ} 23^{\prime} \mathrm{E}$ & $11^{\circ} 47^{\prime} \mathrm{N}$ & - & 736 & 28 & - & - & - & Alley cropping & 400 \\
\hline Raddad et al., (2006) & Sudan & $34^{\circ} 23^{\prime} \mathrm{E}$ & $11^{\circ} 47^{\prime} \mathrm{N}$ & - & 736 & 28 & - & - & - & Alley cropping & 100 \\
\hline Abaker et al., (2016) & Sudan & $13^{\circ} 16^{\prime} \mathrm{N}$ & $30^{\circ} 29^{\prime} \mathrm{E}$ & 560 & 318 & 27 & - & - & - & Parkland & - \\
\hline Abaker et al., (2016) & Sudan & $13^{\circ} 16^{\prime} \mathrm{N}$ & $30^{\circ} 29^{\prime} \mathrm{E}$ & 560 & 318 & 27 & - & - & - & Parkland & - \\
\hline Abaker et al., (2016) & Sudan & $13^{\circ} 19^{\prime} \mathrm{N}$ & $30^{\circ} 10^{\prime} \mathrm{E}$ & 570 & 318 & 27 & - & - & - & Parkland & - \\
\hline Abaker et al., (2016) & Sudan & $13^{\circ} 19^{\prime} \mathrm{N}$ & $30^{\circ} 10^{\prime} \mathrm{E}$ & 570 & 318 & 27 & - & - & - & Parkland & - \\
\hline Abaker et al., (2016) & Sudan & $13^{\circ} 19^{\prime} \mathrm{N}$ & $30^{\circ} 10^{\prime} \mathrm{E}$ & 570 & 318 & 27 & - & - & - & Parkland & - \\
\hline $\begin{array}{l}\text { Materechera and } \\
\text { Mkhabela, (2001) }\end{array}$ & Swaziland & $26^{\circ} 20^{\prime} \mathrm{S}$ & $31^{\circ} 02{ }^{\prime} \mathrm{E}$ & 700 & 760 & - & 41 & 19 & 40 & Natural fallow & - \\
\hline Kimaro et al., (2011) & Tanzania & $6^{\circ} 40^{\prime} \mathrm{S}$ & $37^{\circ} 39^{\prime} \mathrm{E}$ & 475 & 800 & 24 & - & - & - & Rotational woodlot & - \\
\hline Kimaro et al., (2011) & Tanzania & $6^{\circ} 40^{\prime} \mathrm{S}$ & $37^{\circ} 39^{\prime} \mathrm{E}$ & 475 & 800 & 24 & - & - & - & Rotational woodlot & - \\
\hline Kimaro et al., (2011) & Tanzania & $6^{\circ} 40^{\prime} \mathrm{S}$ & $37^{\circ} 39^{\prime} \mathrm{E}$ & 475 & 800 & 24 & - & - & - & Rotational woodlot & - \\
\hline Kimaro et al., (2011) & Tanzania & $6^{\circ} 40^{\prime} \mathrm{S}$ & $37^{\circ} 39^{\prime} \mathrm{E}$ & 475 & 800 & 24 & - & - & - & Rotational woodlot & - \\
\hline Kimaro et al., (2011) & Tanzania & $6^{\circ} 40^{\prime} \mathrm{S}$ & $37^{\circ} 39^{\prime} \mathrm{E}$ & 475 & 800 & 24 & - & - & - & Rotational woodlot & - \\
\hline $\begin{array}{l}\text { Tumwebaze et al., } \\
\text { (2011) }\end{array}$ & Uganda & $0^{\circ} 48^{\prime} \mathrm{N}$ & $32^{\circ} 46^{\prime} \mathrm{E}$ & 1250 & 1560 & $21-25$ & - & - & - & Alley cropping & 320 \\
\hline $\begin{array}{l}\text { Tumwebaze et al., } \\
\text { (2011) }\end{array}$ & Uganda & $0^{\circ} 48^{\prime} \mathrm{N}$ & $32^{\circ} 46^{\prime} \mathrm{E}$ & 1250 & 1560 & $21-25$ & - & - & - & Alley cropping & 320 \\
\hline $\begin{array}{l}\text { Tumwebaze et al., } \\
\text { (2011) }\end{array}$ & Uganda & $0^{\circ} 48^{\prime} \mathrm{N}$ & $32^{\circ} 46^{\prime} \mathrm{E}$ & 1250 & 1560 & $21-25$ & - & - & - & Alley cropping & 320 \\
\hline
\end{tabular}


Tumwebaze et al.,

\begin{tabular}{|c|c|c|c|c|c|c|c|c|c|c|c|}
\hline (2011) & Uganda & $0^{\circ} 48^{\prime} \mathrm{N}$ & $32^{\circ} 46^{\prime} \mathrm{E}$ & 1250 & 1560 & $21-25$ & - & - & - & Alley cropping & 320 \\
\hline $\begin{array}{l}\text { Kaonga and Coleman, } \\
\text { (2008) }\end{array}$ & Zambia & $13^{\circ} 39^{\prime} \mathrm{S}$ & $32^{\circ} 34^{\prime} \mathrm{E}$ & 1030 & 1000 & 23 & 61 & 13 & 26 & $\begin{array}{l}\text { Improved fallow } \\
\text { (coppiced) }\end{array}$ & 10000 \\
\hline $\begin{array}{l}\text { Kaonga and Coleman, } \\
\text { (2008) }\end{array}$ & Zambia & $13^{\circ} 39^{\prime} \mathrm{S}$ & $32^{\circ} 34^{\prime} \mathrm{E}$ & 1030 & 1000 & 23 & 61 & 13 & 26 & $\begin{array}{l}\text { Improved fallow } \\
\text { (coppiced) }\end{array}$ & 10000 \\
\hline $\begin{array}{l}\text { Kaonga and Coleman, } \\
(2008)\end{array}$ & Zambia & $13^{\circ} 39^{\prime} \mathrm{S}$ & $32^{\circ} 34^{\prime} \mathrm{E}$ & 1030 & 1000 & 23 & 61 & 13 & 26 & $\begin{array}{c}\text { Improved fallow } \\
\text { (coppiced) }\end{array}$ & 10000 \\
\hline $\begin{array}{l}\text { Kaonga and Coleman, } \\
(2008)\end{array}$ & Zambia & $13^{\circ} 39^{\prime} \mathrm{S}$ & $32^{\circ} 34^{\prime} \mathrm{E}$ & 1030 & 1000 & 23 & 61 & 13 & 26 & $\begin{array}{l}\text { Improved fallow } \\
\text { (coppiced) }\end{array}$ & 10000 \\
\hline $\begin{array}{l}\text { Kaonga and Coleman, } \\
(2008)\end{array}$ & Zambia & $13^{\circ} 39^{\prime} \mathrm{S}$ & $32^{\circ} 34^{\prime} \mathrm{E}$ & 1030 & 1000 & 23 & 61 & 13 & 26 & $\begin{array}{l}\text { Improved fallow } \\
\text { (coppiced) }\end{array}$ & 10000 \\
\hline $\begin{array}{l}\text { Kaonga and Coleman, } \\
(2008)\end{array}$ & Zambia & $13^{\circ} 39^{\prime} \mathrm{S}$ & $32^{\circ} 34^{\prime} \mathrm{E}$ & 1030 & 1000 & 23 & 61 & 13 & 26 & $\begin{array}{l}\text { Improved fallow } \\
\text { (coppiced) }\end{array}$ & 10000 \\
\hline $\begin{array}{l}\text { Kaonga and Coleman, } \\
(2008)\end{array}$ & Zambia & $13^{\circ} 39^{\prime} \mathrm{S}$ & $32^{\circ} 34^{\prime} \mathrm{E}$ & 1030 & 1000 & 23 & 61 & 13 & 26 & $\begin{array}{l}\text { Improved fallow } \\
\text { (coppiced) }\end{array}$ & 10000 \\
\hline $\begin{array}{l}\text { Kaonga and Coleman, } \\
(2008)\end{array}$ & Zambia & $13^{\circ} 39^{\prime} \mathrm{S}$ & $32^{\circ} 34^{\prime} \mathrm{E}$ & 1030 & 1000 & 23 & 61 & 13 & 26 & $\begin{array}{l}\text { Improved fallow } \\
\text { (coppiced) }\end{array}$ & 10000 \\
\hline $\begin{array}{l}\text { Kaonga and Coleman, } \\
(2008)\end{array}$ & Zambia & $13^{\circ} 39^{\prime} \mathrm{S}$ & $32^{\circ} 34^{\prime} \mathrm{E}$ & 1030 & 1000 & 23 & 61 & 13 & 26 & $\begin{array}{l}\text { Improved fallow } \\
\text { (non coppiced) }\end{array}$ & 10000 \\
\hline $\begin{array}{l}\text { Kaonga and Coleman, } \\
(2008)\end{array}$ & Zambia & $13^{\circ} 39^{\prime} \mathrm{S}$ & $32^{\circ} 34^{\prime} \mathrm{E}$ & 1030 & 1000 & 23 & 61 & 13 & 26 & $\begin{array}{l}\text { Improved fallow } \\
\text { (non coppiced) }\end{array}$ & 10000 \\
\hline $\begin{array}{l}\text { Kaonga and Coleman, } \\
(2008)\end{array}$ & Zambia & $13^{\circ} 39^{\prime} \mathrm{S}$ & $32^{\circ} 34^{\prime} \mathrm{E}$ & 1030 & 1000 & 23 & 61 & 13 & 26 & $\begin{array}{l}\text { Improved fallow } \\
\text { (non coppiced) }\end{array}$ & 10000 \\
\hline $\begin{array}{l}\text { Kaonga and Coleman, } \\
(2008)\end{array}$ & Zambia & $13^{\circ} 39^{\prime} \mathrm{S}$ & $32^{\circ} 34^{\prime} \mathrm{E}$ & 1030 & 1000 & 23 & 61 & 13 & 26 & $\begin{array}{l}\text { Improved fallow } \\
\text { (non coppiced) }\end{array}$ & 10000 \\
\hline $\begin{array}{l}\text { Kaonga and Bayliss- } \\
\text { Smith, (2009) }\end{array}$ & Zambia & $13^{\circ} 39^{\prime} \mathrm{S}$ & $32^{\circ} 34^{\prime} \mathrm{E}$ & 1030 & 1000 & 23 & 61 & 13 & 26 & $\begin{array}{l}\text { Improved fallow } \\
\text { (coppiced) }\end{array}$ & 10000 \\
\hline $\begin{array}{l}\text { Kaonga and Bayliss- } \\
\text { Smith, (2009) }\end{array}$ & Zambia & $13^{\circ} 39^{\prime} \mathrm{S}$ & $32^{\circ} 34^{\prime} \mathrm{E}$ & 1030 & 1000 & 23 & 61 & 13 & 26 & $\begin{array}{l}\text { Improved fallow } \\
\text { (coppiced) }\end{array}$ & 10000 \\
\hline $\begin{array}{l}\text { Kaonga and Bayliss- } \\
\text { Smith, (2009) }\end{array}$ & Zambia & $13^{\circ} 39^{\prime} \mathrm{S}$ & $32^{\circ} 34^{\prime} \mathrm{E}$ & 1030 & 1000 & 23 & 61 & 13 & 26 & $\begin{array}{l}\text { Improved fallow } \\
\text { (coppiced) }\end{array}$ & 10000 \\
\hline $\begin{array}{l}\text { Nyamadzawo et al., } \\
(2008)\end{array}$ & Zimbabwe & $19^{\circ} 35^{\prime} \mathrm{S}$ & $31^{\circ} 14^{\prime} \mathrm{E}$ & 1474 & 750 & - & 71 & 7 & 22 & $\begin{array}{l}\text { Improved fallow } \\
\text { (coppiced) }\end{array}$ & 10000 \\
\hline $\begin{array}{l}\text { Nyamadzawo et al., } \\
(2008)\end{array}$ & Zimbabwe & $19^{\circ} 35^{\prime} \mathrm{S}$ & $31^{\circ} 14^{\prime} \mathrm{E}$ & 1474 & 750 & - & 71 & 7 & 22 & $\begin{array}{l}\text { Improved fallow } \\
\text { (non coppiced) }\end{array}$ & 10000 \\
\hline
\end{tabular}




\begin{tabular}{|c|c|c|c|c|c|c|c|c|c|c|}
\hline \multirow[b]{2}{*}{ Reference } & \multirow[b]{2}{*}{ Tree species } & \multirow[b]{2}{*}{ Crop species } & \multirow{2}{*}{$\begin{array}{l}\text { Number } \\
\text { of years }\end{array}$} & \multirow{2}{*}{$\begin{array}{c}\text { Maximum } \\
\text { Sampling } \\
\text { depth }(\mathrm{cm})\end{array}$} & \multicolumn{2}{|c|}{$\operatorname{SOC}\left(\mathrm{kg} \mathrm{ha}^{-1}\right)$} & \multicolumn{2}{|c|}{$\begin{array}{l}\text { SOC storage rate } \\
\left(\mathbf{M g ~ C ~ h a}^{-1} \mathbf{y r}^{-1}\right)\end{array}$} & \multicolumn{2}{|c|}{$\begin{array}{c}\text { SOC storage rate } \\
\left(\% \mathrm{yr}^{-1}\right)\end{array}$} \\
\hline & & & & & Control & Initial & Diachronic & Synchronic & Diachronic & Synchronic \\
\hline Baumert et al., (2016) & Jatropha curcas L. & Sorghum & 2 & 40 & 25158 & - & - & -2.41 & - & -96 \\
\hline Baumert et al., (2016) & Jatropha curcas L. & Sorghum & 4 & 20 & 40466 & - & - & -4.63 & - & -114 \\
\hline Baumert et al., (2016) & Jatropha curcas L. & Sorghum & 3 & 40 & 35181 & - & - & -0.46 & - & -13 \\
\hline Baumert et al., (2016) & Jatropha curcas L. & Sorghum & 2 & 40 & 58062 & - & - & 3.89 & - & 67 \\
\hline Baumert et al., (2016) & Jatropha curcas L. & Sorghum & 3 & 20 & 19582 & - & - & -0.19 & - & -9 \\
\hline Baumert et al., (2016) & Jatropha curcas L. & Sorghum & 4 & 40 & 39110 & - & - & -0.16 & - & -4 \\
\hline Baumert et al., (2016) & Jatropha curcas L. & Sorghum & 16 & 40 & 30629 & - & - & 0.46 & - & 15 \\
\hline Baumert et al., (2016) & Jatropha curcas L. & Sorghum & 3 & 40 & 37805 & - & - & 1.13 & - & 30 \\
\hline Baumert et al., (2016) & Jatropha curcas L. & Sorghum & 3 & 20 & 19460 & - & - & 0.56 & - & 29 \\
\hline Baumert et al., (2016) & Jatropha curcas L. & Sorghum & 3 & 40 & 37805 & - & - & -2.71 & - & -72 \\
\hline Baumert et al., (2016) & Jatropha curcas L. & Sorghum & 3 & 40 & 60479 & - & - & -9.64 & - & -159 \\
\hline Gelaw et al., (2014) & Faidherbia albida & $\begin{array}{l}\text { Maize } \\
\text { Eragrostis tef, } \\
\text { Vicia faba, } \\
\text { Eleusine } \\
\text { coracana }\end{array}$ & 50 & 30 & 16100 & - & - & 0.19 & - & 12 \\
\hline Rimhanen et al., (2016) & Multiple tree species & Maize & 6 & 15 & 59329 & - & - & 0.72 & - & 12 \\
\hline Rimhanen et al., (2016) & Multiple tree species & Maize. & 10 & 15 & 40160 & - & - & 2.00 & - & 50 \\
\hline Rimhanen et al., (2016) & Multiple tree species & $\begin{array}{l}\text { Phaseolus } \\
\text { vulgaris } \mathrm{L} ., \\
\text { Zea mays L. }\end{array}$ & 10 & 15 & 53671 & - & - & -0.10 & - & -2 \\
\hline Rimhanen et al., (2016) & Multiple tree species & $\begin{array}{l}\text { Triticum spp. } \\
\text { L. }\end{array}$ & 20 & 15 & 17759 & - & - & 1.06 & - & 60 \\
\hline Rimhanen et al., (2016) & Multiple tree species & $\begin{array}{l}\text { Phaseolus } \\
\text { vulgaris L., } \\
\text { Triticum spp. } \\
\text { L. } \\
\end{array}$ & 10 & 15 & 38674 & - & - & -0.17 & - & -5 \\
\hline Rimhanen et al., (2016) & Multiple tree species & Maize & 7 & 15 & 37092 & - & - & 2.03 & - & 55 \\
\hline
\end{tabular}


Allium cepa L.,

Eragrostis tef

Rimhanen et al., (2016)

Multiple tree species (Zucc.) Trotter,

Triticum spp.

\begin{tabular}{|c|c|c|c|c|c|c|c|c|c|c|}
\hline Rimhanen et al., (2016) & Multiple tree species & $\begin{array}{l}\text { Phaseolus } \\
\text { vulgaris } \mathrm{L} ., \\
\text { Zea mays } \mathrm{L} . \\
\end{array}$ & 6 & 15 & 33242 & - & - & 1.33 & - & 40 \\
\hline Verchot et al., (2011) & $\begin{array}{l}\text { Tephrosia candida, } T \text {. } \\
\text { vogelii, Crotalaria } \\
\text { paulina, } C . \\
\text { grahamiana. }\end{array}$ & Maize & 7 & 20 & - & - & - & 0.40 & - & - \\
\hline Verchot et al., (2011) & $\begin{array}{l}\text { Tephrosia candida, } T \text {. } \\
\text { vogelii, Crotalaria } \\
\text { paulina, } C . \\
\text { grahamiana. }\end{array}$ & Maize & 7 & 20 & - & - & - & 0.37 & - & - \\
\hline Makumba et al., (2007) & Gliricidia sepium & Maize & 10 & 20 & 19000 & - & - & 1.10 & - & 58 \\
\hline Makumba et al., (2007) & Gliricidia sepium & Maize & 10 & 200 & 64000 & - & - & 5.90 & - & 92 \\
\hline Makumba et al., (2007) & Gliricidia sepium & Maize & 10 & 20 & 22000 & - & - & 1.14 & - & 28 \\
\hline Makumba et al., (2007) & Gliricidia sepium & Maize & 7 & 200 & 73000 & - & - & 10.86 & - & 149 \\
\hline Diels et al., (2004) & Leucaena leucocephala & $\begin{array}{l}\text { Maize, Cowpea } \\
(-N P K)\end{array}$ & 16 & 12 & 7300 & - & - & 0.21 & - & 29 \\
\hline Diels et al., (2004) & Leucaena leucocephala & $\begin{array}{l}\text { Maize, Cowpea } \\
(+\mathrm{NPK})\end{array}$ & 16 & 12 & 8000 & - & - & 0.23 & - & 28 \\
\hline Diels et al., (2004) & Senna siamea & $\begin{array}{l}\text { Maize, Cowpea } \\
(-\mathrm{NPK})\end{array}$ & 16 & 12 & 7300 & - & - & 0.27 & - & 37 \\
\hline Diels et al., (2004) & Senna siamea & $\begin{array}{l}\text { Maize, Cowpea } \\
(+\mathrm{NPK})\end{array}$ & 16 & 12 & 8000 & - & - & 0.33 & - & 41 \\
\hline Bright et al., (2017) & Piliostigma reticulatum & $\begin{array}{l}\text { Millet, } \\
\text { Groundnut } \\
(0 * \mathrm{NPK})\end{array}$ & 13 & 10 & 3145 & - & - & 0.16 & - & 51 \\
\hline Bright et al., (2017) & Piliostigma reticulatum & $\begin{array}{l}\text { Millet, } \\
\text { Groundnut } \\
\left(0.5^{*} \mathrm{NPK}\right) \\
\end{array}$ & 13 & 10 & 3411 & - & - & 0.17 & - & 51 \\
\hline Bright et al., (2017) & Piliostigma reticulatum & $\begin{array}{l}\text { Millet, } \\
\text { Groundnut } \\
(1 * \mathrm{NPK})\end{array}$ & 13 & 10 & 3131 & - & - & 0.16 & - & 51 \\
\hline
\end{tabular}




\begin{tabular}{|c|c|c|c|c|c|c|c|c|c|c|}
\hline Bright et al., (2017) & Piliostigma reticulatum & $\begin{array}{l}\text { Millet, } \\
\text { Groundnut } \\
\left(1.5^{*} \mathrm{NPK}\right) \\
\end{array}$ & 13 & 10 & 3178 & - & - & 0.20 & - & 64 \\
\hline Raddad et al., (2006) & Acacia senegal & $\begin{array}{l}\text { Sorghum, } \\
\text { Sesame }\end{array}$ & 4 & 25 & - & 11340 & 0.79 & - & 70 & - \\
\hline Raddad et al., (2006) & Acacia senegal & $\begin{array}{l}\text { Sorghum, } \\
\text { Sesame }\end{array}$ & 4 & 25 & - & 11340 & 0.02 & - & 1 & - \\
\hline Abaker et al., (2016) & Acacia senegal & $\begin{array}{l}\text { Grasses, C3 } \\
\text { herbs }\end{array}$ & 15 & 50 & 9500 & - & - & 0.03 & - & 3 \\
\hline Abaker et al., (2016) & Acacia senegal & $\begin{array}{l}\text { Grasses, C3 } \\
\text { herbs }\end{array}$ & 24 & 50 & 9500 & - & - & 0.06 & - & 6 \\
\hline Abaker et al., (2016) & Acacia senegal & $\begin{array}{l}\text { Grasses, C3 } \\
\text { herbs }\end{array}$ & 7 & 50 & 8670 & - & - & -0.03 & - & -3 \\
\hline Abaker et al., (2016) & Acacia senegal & $\begin{array}{l}\text { Grasses, C3 } \\
\text { herbs }\end{array}$ & 15 & 50 & 8670 & - & - & 0.08 & - & 9 \\
\hline Abaker et al., (2016) & Acacia senegal & $\begin{array}{l}\text { Grasses, C3 } \\
\text { herbs }\end{array}$ & 20 & 50 & 8670 & - & - & 0.19 & - & 22 \\
\hline $\begin{array}{l}\text { Materechera and Mkhabela, } \\
\text { (2001) }\end{array}$ & $\begin{array}{l}\text { Themeda triandra } \\
\text { grass, Combretum } \\
\text { imberbe, Sclerocarya } \\
\text { birrea, thorn scrub }\end{array}$ & Maize & 12 & 15 & 39780 & - & - & 1.12 & - & 28 \\
\hline Kimaro et al., (2011) & Acacia crassicarpa & Maize & 5 & 15 & 13000 & - & - & 0.56 & - & 43 \\
\hline Kimaro et al., (2011) & Acacia mangium & Maize & 5 & 15 & 13000 & - & - & 2.52 & - & 194 \\
\hline Kimaro et al., (2011) & Acacia polyacantha & Maize & 5 & 15 & 13000 & - & - & 1.72 & - & 132 \\
\hline Kimaro et al., (2011) & Gliricidia sepium & Maize & 5 & 15 & 13000 & - & - & 1.16 & - & 89 \\
\hline Kimaro et al., (2011) & Acacia nilotica & Maize & 5 & 15 & 13000 & - & - & 1.94 & - & 149 \\
\hline Tumwebaze et al., (2011) & $\begin{array}{l}\text { Casuarina equisetifolia } \\
\text { L. }\end{array}$ & Maize & 11 & 100 & 152060 & - & - & 10.89 & - & 72 \\
\hline Tumwebaze et al., (2011) & $\begin{array}{l}\text { Grevillea robusta A. } \\
\text { Cunn. }\end{array}$ & Maize & 11 & 100 & 152060 & - & - & 13.84 & - & 91 \\
\hline Tumwebaze et al., (2011) & Maesopsis eminii Engl. & Maize & 11 & 100 & 152060 & - & - & 14.29 & - & 94 \\
\hline Tumwebaze et al., (2011) & $\begin{array}{l}\text { Markhamia lutea } K . \\
\text { Schum. }\end{array}$ & Maize & 11 & 100 & 152060 & - & - & 11.76 & - & 77 \\
\hline Kaonga and Coleman, (2008) & $\begin{array}{l}\text { Leucaena. } \\
\text { leucocephala }\end{array}$ & Maize (-NPK) & 10 & 20 & 22200 & - & - & 1.52 & - & 68 \\
\hline
\end{tabular}




\begin{tabular}{|c|c|c|c|c|c|c|c|c|c|c|}
\hline Kaonga and Coleman, (2008) & $\begin{array}{l}\text { Leucaena. } \\
\text { leucocephala }\end{array}$ & Maize (+NPK) & 10 & 20 & 26200 & - & - & 1.12 & - & 43 \\
\hline Kaonga and Coleman, (2008) & Gliricidia sepium & Maize (-NPK) & 10 & 20 & 22200 & - & - & 1.17 & - & 53 \\
\hline Kaonga and Coleman, (2008) & Gliricidia sepium & Maize (+NPK) & 10 & 20 & 26200 & - & - & 0.77 & - & 29 \\
\hline Kaonga and Coleman, (2008) & $\begin{array}{l}\text { Callliandra } \\
\text { callothyrsus }\end{array}$ & Maize (-NPK) & 10 & 20 & 22200 & - & - & 1.10 & - & 150 \\
\hline Kaonga and Coleman, (2008) & $\begin{array}{l}\text { Calliandra } \\
\text { callothyrsus }\end{array}$ & Maize (+NPK) & 10 & 20 & 26200 & - & - & 0.70 & - & 27 \\
\hline Kaonga and Coleman, (2008) & Senna siamea & Maize (-NPK) & 10 & 20 & 22200 & - & - & 0.83 & - & 37 \\
\hline Kaonga and Coleman, (2008) & Senna siamea & Maize (+NPK) & 10 & 20 & 26200 & - & - & 0.43 & - & 16 \\
\hline Kaonga and Coleman, (2008) & Tephrosia vogelli & Maize (-NPK) & 10 & 20 & 22200 & - & - & 0.90 & - & 41 \\
\hline Kaonga and Coleman, (2008) & Tephrosia vogelli & Maize (+NPK) & 10 & 20 & 26200 & - & - & 0.50 & - & 19 \\
\hline Kaonga and Coleman, (2008) & Cajanus cajan & Maize (-NPK) & 10 & 20 & 22200 & - & - & 0.79 & - & 36 \\
\hline Kaonga and Coleman, (2008) & Cajanus cajan & Maize (+NPK) & 10 & 20 & 26200 & - & - & 0.39 & - & 15 \\
\hline Kaonga and Coleman, (2008) & Sesbania sesban & Maize (-NPK) & 10 & 20 & 22200 & - & - & 0.51 & - & 23 \\
\hline Kaonga and Coleman, (2008) & Sesbania sesban & Maize (+NPK) & 10 & 20 & 26200 & - & - & 0.11 & - & 4 \\
\hline $\begin{array}{l}\text { Kaonga and Bayliss-Smith, } \\
\text { (2009) }\end{array}$ & Leucaena leucocephala & $\begin{array}{l}\text { Maize, Cowpea } \\
\text { (-NPK) }\end{array}$ & 10 & 200 & 240000 & - & - & 5.10 & - & 21 \\
\hline $\begin{array}{l}\text { Kaonga and Bayliss-Smith, } \\
\text { (2009) }\end{array}$ & Senna siamea & $\begin{array}{l}\text { Maize, Cowpea } \\
(+\mathrm{NPK})\end{array}$ & 10 & 200 & 240000 & - & - & 4.60 & - & 19 \\
\hline $\begin{array}{l}\text { Kaonga and Bayliss-Smith, } \\
(2009)\end{array}$ & Gliricidia sepium & $\begin{array}{l}\text { Maize, Cowpea } \\
(+\mathrm{NPK})\end{array}$ & 10 & 200 & 240000 & - & - & 3.00 & - & 13 \\
\hline Nyamadzawo et al., (2008) & Acacia angustissima & Maize & 8 & 20 & 16900 & - & - & 1.18 & - & 70 \\
\hline Nyamadzawo et al., (2008) & Sesbania sesban & Maize & 8 & 20 & 16900 & - & - & 1.06 & - & 63 \\
\hline
\end{tabular}

Table S3: Reference list and details of the selected publications for the analysis of SOC storage under conservation agriculture systems 


\begin{tabular}{|c|c|c|c|c|c|c|c|c|c|c|}
\hline \multirow{2}{*}{$\begin{array}{l}\text { Reference } \\
\text { Agbede, (2008) }\end{array}$} & \multirow{2}{*}{$\begin{array}{c}\text { Country } \\
\text { Nigeria } \\
\end{array}$} & \multicolumn{2}{|c|}{ Coordinates } & \multirow{2}{*}{$\frac{\text { Altitude (masl) }}{-}$} & \multirow{2}{*}{$\begin{array}{c}\begin{array}{c}\text { Mean annual } \\
\text { precipitation } \\
\text { (mm) }\end{array} \\
2688 \\
\end{array}$} & \multirow{2}{*}{$\begin{array}{c}\begin{array}{c}\text { Mean annual } \\
\text { temperature } \\
\left({ }^{\circ} \mathbf{C}\right)\end{array} \\
26 \\
\end{array}$} & \multicolumn{3}{|c|}{ Sand/Silt/Clay (\%) } & \multirow{2}{*}{$\begin{array}{c}\text { CA Type } \\
\text { NT + residues }\end{array}$} \\
\hline & & $5^{\circ} 12^{\prime} \mathrm{E}$ & $7^{\circ} 12^{\prime} \mathrm{N}$ & & & & 70 & 13 & 17 & \\
\hline Agbede, (2008) & Nigeria & $5^{\circ} 12^{\prime} \mathrm{E}$ & $7^{\circ} 12^{\prime} \mathrm{N}$ & - & 2688 & 26 & 70 & 13 & 17 & NT \\
\hline Agele et al., (2005) & Nigeria & $5^{\circ} 10^{\prime} \mathrm{E}$ & $7^{\circ} 5^{\prime} \mathrm{N}$ & - & 1328 & 31 & 18 & 25 & 57 & NT + residues \\
\hline Agele et al., (2005) & Nigeria & $5^{\circ} 10^{\prime} \mathrm{E}$ & $7^{\circ} 5^{\prime} \mathrm{N}$ & - & 1328 & 31 & 18 & 25 & 57 & NT \\
\hline $\begin{array}{l}\text { Ambassa-Kiki and Nill, } \\
\text { (1999) }\end{array}$ & Cameroon & - & - & - & 1600 & - & 31 & 26 & 46 & $\mathrm{NT}+$ rotation \\
\hline Anikwe and Ubochi, (2007) & Nigeria & $7^{\circ} 15^{\prime} \mathrm{E}$ & $6^{\circ} 52^{\prime} \mathrm{N}$ & 450 & $1700-2010$ & - & 44 & 40 & 16 & NT \\
\hline Anikwe et al., (2016) & Nigeria & $7^{\circ} 54^{\prime} \mathrm{E}$ & $6^{\circ} 29^{\prime} \mathrm{N}$ & 450 & $1700-2010$ & - & 44 & 40 & 16 & NT \\
\hline Barthès, et al., (2004) & Benin & $2^{\circ} 24^{\prime} \mathrm{E}$ & $6^{\circ} 24^{\prime} \mathrm{N}$ & - & 1200 & 27 & - & - & - & $\begin{array}{c}\mathrm{NT}+\text { residues }+ \\
\text { intercropping/rotation }\end{array}$ \\
\hline Lal, (1998) & Nigeria & - & - & - & 1250 & - & - & - & - & NT \\
\hline Lal, (1998) & Nigeria & - & - & - & 1250 & - & - & - & - & NT + residues \\
\hline Mloza-Banda et al., (2016) & Malawi & $\begin{array}{l}34^{\circ} 40^{\prime}- \\
35^{\circ} 30^{\prime} \mathrm{E}\end{array}$ & $\begin{array}{r}14^{\circ} 30^{\prime} \\
15^{\circ} 20^{\prime} \mathrm{S} \\
\end{array}$ & 625 & 828 & 23 & $37-45$ & $20-16$ & $43-38$ & $\mathrm{NT}+$ residues \\
\hline Mloza-Banda et al., (2014) & Malawi & $\begin{array}{l}33^{\circ} 14^{\prime}- \\
35^{\circ} 56^{\prime} \mathrm{E} \\
\end{array}$ & $\begin{array}{c}13^{\circ} 29^{\prime} \\
15^{\circ} 20^{\prime} \mathrm{S} \\
\end{array}$ & 1200 & 1000 & 21 & $40-70$ & $10-20$ & $20-40$ & $\mathrm{NT}+$ residues \\
\hline Mujuru et al., (2013) & Zimbabwe & $31^{\circ} 43^{\prime} \mathrm{E}$ & $17^{\circ} 00^{\prime} \mathrm{S}$ & $1000-1800$ & $750-1000$ & - & 89 & 7 & 5 & $\mathrm{NT}+$ residues \\
\hline Mujuru et al., (2013) & Zimbabwe & $31^{\circ} 44^{\prime} \mathrm{E}$ & $17^{\circ} 42^{\prime} \mathrm{S}$ & $1000-1800$ & $750-1000$ & - & 54 & 20 & 26 & $\mathrm{NT}+$ residues \\
\hline Mujuru et al., (2013) & Zimbabwe & $31^{\circ} 43^{\prime} \mathrm{E}$ & $17^{\circ} 00^{\prime} \mathrm{S}$ & $1000-1800$ & $750-1000$ & - & 89 & 7 & 5 & $\begin{array}{c}\text { NT + residues + } \\
\text { intercropping/rotation }\end{array}$ \\
\hline Mujuru et al., (2013) & Zimbabwe & $31^{\circ} 44^{\prime} \mathrm{E}$ & $17^{\circ} 42^{\prime} \mathrm{S}$ & $1000-1800$ & $750-1000$ & - & 54 & 20 & 26 & $\begin{array}{c}\mathrm{NT}+\text { residues }+ \\
\text { intercropping/rotation }\end{array}$ \\
\hline Gwenzi et al., (2009) & Zimbabwe & $32^{\circ} 21^{\prime} \mathrm{E}$ & $20^{\circ} 21^{\prime} \mathrm{S}$ & 444 & 482 & 24 & 78 & 11 & 11 & $\begin{array}{c}\text { NT + residues + } \\
\text { intercropping/rotation }\end{array}$ \\
\hline Gwenzi et al., (2009) & Zimbabwe & $32^{\circ} 21^{\prime} \mathrm{E}$ & $20^{\circ} 21^{\prime} \mathrm{S}$ & 444 & 482 & 24 & 78 & 11 & 11 & $\begin{array}{c}\mathrm{NT}+\text { residues }+ \\
\text { intercropping/rotation }\end{array}$ \\
\hline Ngome et al., (2011) & Kenya & $34^{\circ} 46^{\prime} \mathrm{E}$ & $0^{\circ} 16^{\prime} \mathrm{N}$ & 1534 & 1978 & 21 & 13 & 34 & 53 & $\begin{array}{c}\mathrm{NT}+\text { residues }+ \\
\text { intercropping/rotation }\end{array}$ \\
\hline Ngome et al., (2011) & Kenya & $34^{\circ} 47^{\prime} \mathrm{E}$ & $0^{\circ} 19^{\prime} \mathrm{N}$ & 1558 & 1612 & 21 & 61 & 20 & 19 & $\begin{array}{c}\mathrm{NT}+\text { residues }+ \\
\text { intercropping/rotation }\end{array}$ \\
\hline
\end{tabular}




\begin{tabular}{|c|c|c|c|c|c|c|c|c|c|c|}
\hline Ngome et al., (2011) & Kenya & $34^{\circ} 51^{\prime} \mathrm{E}$ & $0^{\circ} 14^{\prime} \mathrm{N}$ & 1569 & 2232 & 21 & 11 & 27 & 62 & $\begin{array}{c}\mathrm{NT}+\text { residues }+ \\
\text { intercropping/rotation }\end{array}$ \\
\hline Nyamadzawo et al., (2008) & Zimbabwe & $31^{\circ} 14^{\prime} \mathrm{E}$ & $19^{\circ} 35^{\prime} \mathrm{S}$ & 1474 & 750 & - & 71 & 7 & 22 & $\begin{array}{c}\mathrm{NT}+\text { residues }+ \\
\text { intercropping/rotation }\end{array}$ \\
\hline $\begin{array}{l}\text { Ojeniyi and Adekayode, } \\
\text { (1999) }\end{array}$ & Nigeria & $5^{\circ} 15^{\prime} \mathrm{E}$ & $7^{\circ} 15^{\prime} \mathrm{N}$ & 210 & - & - & - & - & - & $\mathrm{NT}+?+$ rotation \\
\hline Paul et al., (2015) & Kenya & $34^{\circ} 24^{\prime} \mathrm{E}$ & $0^{\circ} 06^{\prime} \mathrm{N}$ & 1420 & 1800 & - & 24 & 18 & 58 & $\mathrm{NT}+$ rotation \\
\hline Paul et al., (2015) & Kenya & $34^{\circ} 24^{\prime} \mathrm{E}$ & $0^{\circ} 06^{\prime} \mathrm{N}$ & 1420 & 1800 & - & 24 & 18 & 58 & $\mathrm{NT}+$ residues + rotation \\
\hline Thierfelder and Wall, (2012) & Zimbabwe & $30^{\circ} 98^{\prime} \mathrm{E}$ & $17^{\circ} 57^{\prime} \mathrm{S}$ & 1136 & 884 & 18 & 77 & 16 & 7 & $\mathrm{NT}+$ residues \\
\hline Thierfelder and Wall, (2012) & Zimbabwe & $30^{\circ} 98^{\prime} \mathrm{E}$ & $17^{\circ} 57^{\prime} \mathrm{S}$ & 1136 & 884 & 18 & 77 & 16 & 7 & $\mathrm{NT}+$ residues \\
\hline Thierfelder et al., (2012a) & Zimbabwe & $30^{\circ} 98^{\prime} \mathrm{E}$ & $17^{\circ} 57^{\prime} \mathrm{S}$ & 1136 & 884 & 18 & 77 & 16 & 7 & $\begin{array}{c}\mathrm{NT}+\text { residues }+ \\
\text { intercropping/rotation }\end{array}$ \\
\hline Thierfelder et al., (2012b) & Zambia & $32^{\circ} 61^{\prime} \mathrm{E}$ & $13^{\circ} 70^{\prime} \mathrm{S}$ & 1070 & 748 & 19 & 82 & 6 & 12 & $\mathrm{NT}+$ residues \\
\hline Thierfelder et al., (2012b) & Zambia & $32^{\circ} 61^{\prime} \mathrm{E}$ & $13^{\circ} 70^{\prime} \mathrm{S}$ & 1070 & 748 & 19 & 82 & 6 & 12 & $\begin{array}{c}\mathrm{NT}+\text { residues + } \\
\text { intercropping/rotation }\end{array}$ \\
\hline Thierfelder et al., (2013) & Zambia & $32^{\circ} 61^{\prime} \mathrm{E}$ & $13^{\circ} 70^{\prime} \mathrm{S}$ & 1070 & 748 & 19 & 82 & 6 & 12 & $\begin{array}{c}\mathrm{NT}+\text { residues }+ \\
\text { intercropping/rotation }\end{array}$ \\
\hline Okeyo, et al., (2016) & Kenya & $34^{\circ} 25^{\prime} \mathrm{E}$ & $0^{\circ} 08^{\prime} \mathrm{N}$ & 1320 & 1769 & 23 & 2 & 31 & 67 & $\mathrm{NT}+$ intercropping /rotation \\
\hline
\end{tabular}




\begin{tabular}{|c|c|c|c|c|c|c|c|c|c|c|}
\hline \multirow[b]{2}{*}{ Reference } & \multirow[b]{2}{*}{ Crop species } & \multirow{2}{*}{$\begin{array}{l}\text { Rotational crop } \\
\text { species }\end{array}$} & \multirow{2}{*}{$\begin{array}{l}\text { Number } \\
\text { of years }\end{array}$} & \multirow{2}{*}{$\begin{array}{c}\text { Maximum } \\
\text { Sampling } \\
\text { depth }(\mathrm{cm})\end{array}$} & \multicolumn{2}{|c|}{$\operatorname{SOC}\left(\mathrm{kg} \mathrm{ha}^{-1}\right)$} & \multicolumn{2}{|c|}{ 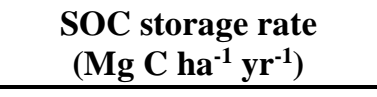 } & \multicolumn{2}{|c|}{$\begin{array}{c}\text { SOC storage rate } \\
\left(\% \mathrm{yr}^{-1}\right)\end{array}$} \\
\hline & & & & & Control. & Initial & Diachronic & Synchronic & Diachronic & Synchronic \\
\hline Agbede, (2008) & Cocoyam & None & 2 & 20 & 3343 & 5630 & -0.55 & 0.59 & -98 & 177 \\
\hline Agbede, (2008) & Cocoyam & None & 2 & 20 & 3343 & 5630 & -0.60 & 0.54 & -107 & 162 \\
\hline Agele et al., (2005) & Maize & None & 2 & 15 & 68030 & - & & 1.96 & - & 29 \\
\hline Agele et al., (2005) & Maize & None & 2 & 15 & 48732 & 44649 & 6.86 & 4.81 & 154 & 99 \\
\hline $\begin{array}{l}\text { Ambassa-Kiki and Nill, } \\
\text { (1999) }\end{array}$ & Maize & Groundnuts & 2 & 5 & 7865 & 11000 & -0.19 & 1.38 & -17 & 175 \\
\hline Anikwe and Ubochi, (2007) & Sweet potato & None & 2 & 30 & 43667 & 72075 & -10.22 & 3.98 & -142 & 91 \\
\hline \multicolumn{11}{|l|}{ Anikwe et al., (2016) } \\
\hline & $\begin{array}{l}\text { Groundnut, bambara } \\
\text { nut, soybean }\end{array}$ & None & 2 & 30 & 9611 & 8208 & 3.70 & 2.99 & 450 & 312 \\
\hline Barthès, et al., (2004) & Maize & Mucuna pruriens & 11 & 40 & 24200 & 27700 & 1.24 & 1.56 & 45 & 65 \\
\hline Lal, (1998) & Maize & None & 5 & 10 & 12398 & 25364 & -1.12 & 1.50 & -44 & 118 \\
\hline Lal, (1998) & Maize & None & 5 & 10 & 12398 & 23819 & -0.17 & 2.11 & -7 & 170 \\
\hline Mloza-Banda et al., (2016) & Maize & None & 5 & 20 & 12740 & - & - & 3.73 & - & 292 \\
\hline Mloza-Banda et al., (2014) & Maize & None & 4 & 20 & 27166 & - & - & 12.17 & - & 448 \\
\hline Mujuru et al., (2013) & Maize & None & 4 & 10 & 5160 & 6384 & -0.00 & 0.30 & -0 & 59 \\
\hline Mujuru et al., (2013) & Maize & None & 4 & 10 & 19130 & 16080 & 0.53 & -0.23 & 33 & -12 \\
\hline Mujuru et al., (2013) & Maize & Cowpea & 4 & 10 & 5160 & 5453 & 0.36 & 0.44 & 67 & 85 \\
\hline Mujuru et al., (2013) & Maize & Soybean & 4 & 10 & 19130 & 17640 & 0.10 & -0.27 & 5.5 & -14 \\
\hline Gwenzi et al., (2009) & Wheat & Cotton & 4 & 60 & 27800 & 32800 & 1.77 & 3.02 & 54 & 109 \\
\hline Gwenzi et al., (2009) & Wheat & Cotton & 5 & 60 & 27800 & 32900 & 1.74 & 2.76 & 53 & 99 \\
\hline Ngome et al., (2011) & Maize & Arachis pintö̈ & 1 & 15 & 66600 & 66267 & 5.13 & 4.80 & 77 & 72 \\
\hline Ngome et al., (2011) & Maize & Arachis pintö̈ & 1 & 15 & 21800 & 21594 & 3.81 & 3.60 & 176 & 165 \\
\hline Ngome et al., (2011) & Maize & Arachis pintö̈ & 1 & 15 & 46900 & 46536 & 4.76 & 4.40 & 102 & 94 \\
\hline Nyamadzawo et al., (2008) & Maize & Sesbania sesban & 2 & 20 & 16800 & 25400 & -2.45 & 1.85 & -96 & 110 \\
\hline
\end{tabular}


Ojeniyi and Adekayode,

\begin{tabular}{|c|c|c|c|c|c|c|c|c|c|c|}
\hline (1999) & Maize & Cowpea & 3 & 15 & $2361-$ & - & - & 0.28 & - & 119 \\
\hline Paul et al., (2015) & Maize & Soybean & 9 & 30 & 59844 & & - & -0.37 & - & -6 \\
\hline Paul et al., (2015) & Maize & Soybean & 9 & 30 & 60428 & & - & 0.66 & - & 11 \\
\hline Thierfelder and Wall, (2012) & Maize & None & 4 & 30 & 18700 & 13900 & 2.12 & 0.92 & 153 & 49 \\
\hline Thierfelder and Wall, (2012) & Maize & None & 4 & 30 & 18700 & 16500 & 1.35 & 0.80 & 82 & 43 \\
\hline Thierfelder et al., (2012a) & Maize & Legume & 4 & 30 & 18400 & - & - & 1.57 & - & 86 \\
\hline Thierfelder et al., (2012b) & Maize & None & 5 & 30 & 23400 & 30300 & 0.08 & 1.46 & 3 & 62 \\
\hline Thierfelder et al., (2012b) & Maize & Cotton & 5 & 30 & 23400 & 27000 & 1.06 & 1.78 & 39 & 76 \\
\hline Thierfelder et al., (2013) & Maize & Cotton & 3 & 30 & 23400 & 27700 & 0.73 & 2.17 & 26 & 93 \\
\hline Okeyo, et al., (2016) & Maize & Common bean & 7 & 30 & 71300 & - & - & 0.27 & - & 4 \\
\hline Okeyo, et al., (2016) & Maize & Common bean & 7 & 30 & 71300 & - & - & 0.39 & - & 5 \\
\hline
\end{tabular}




\section{Agroforestry (all depths)}

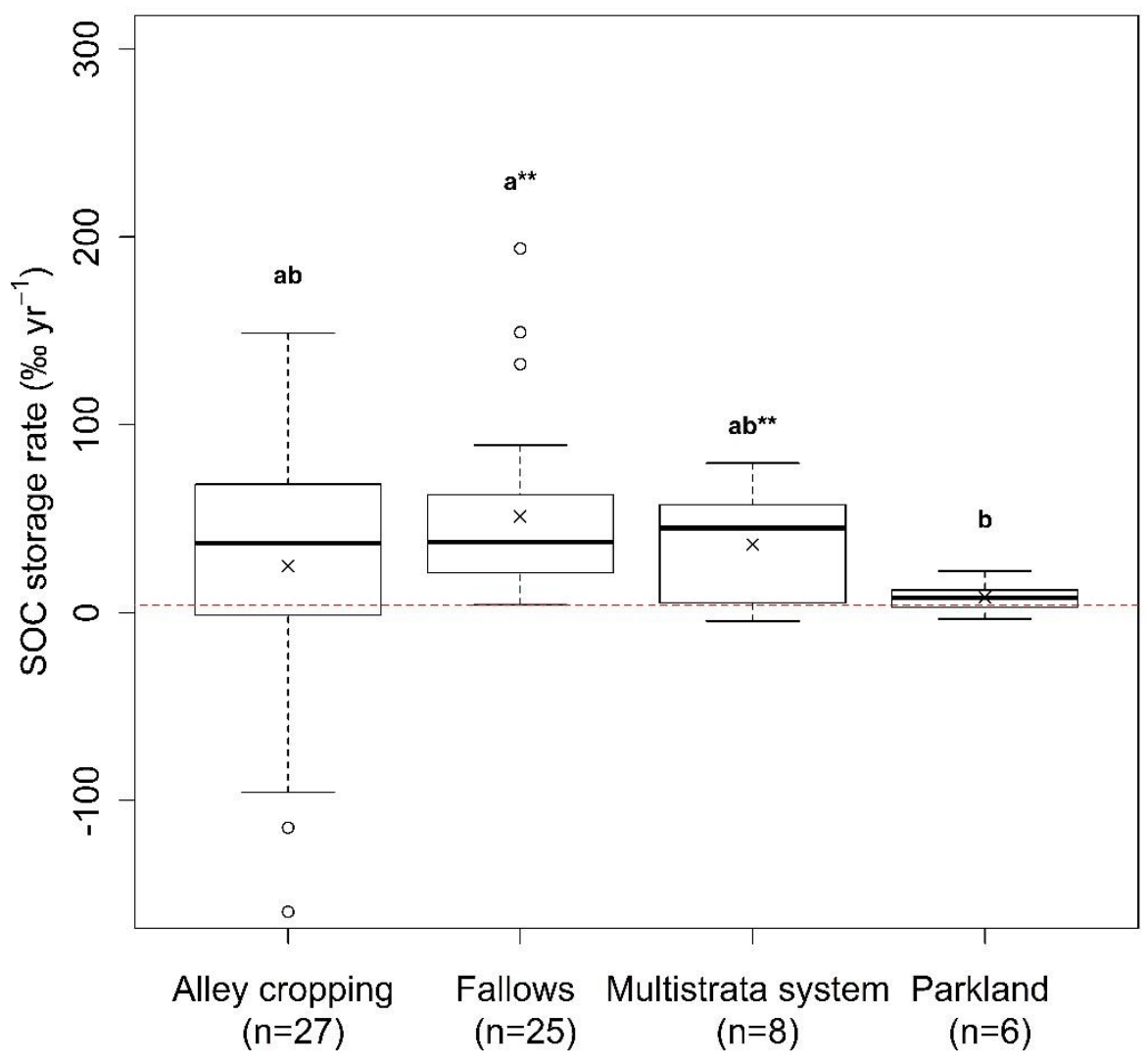

Agroforestry $(0-40 \mathrm{~cm})$

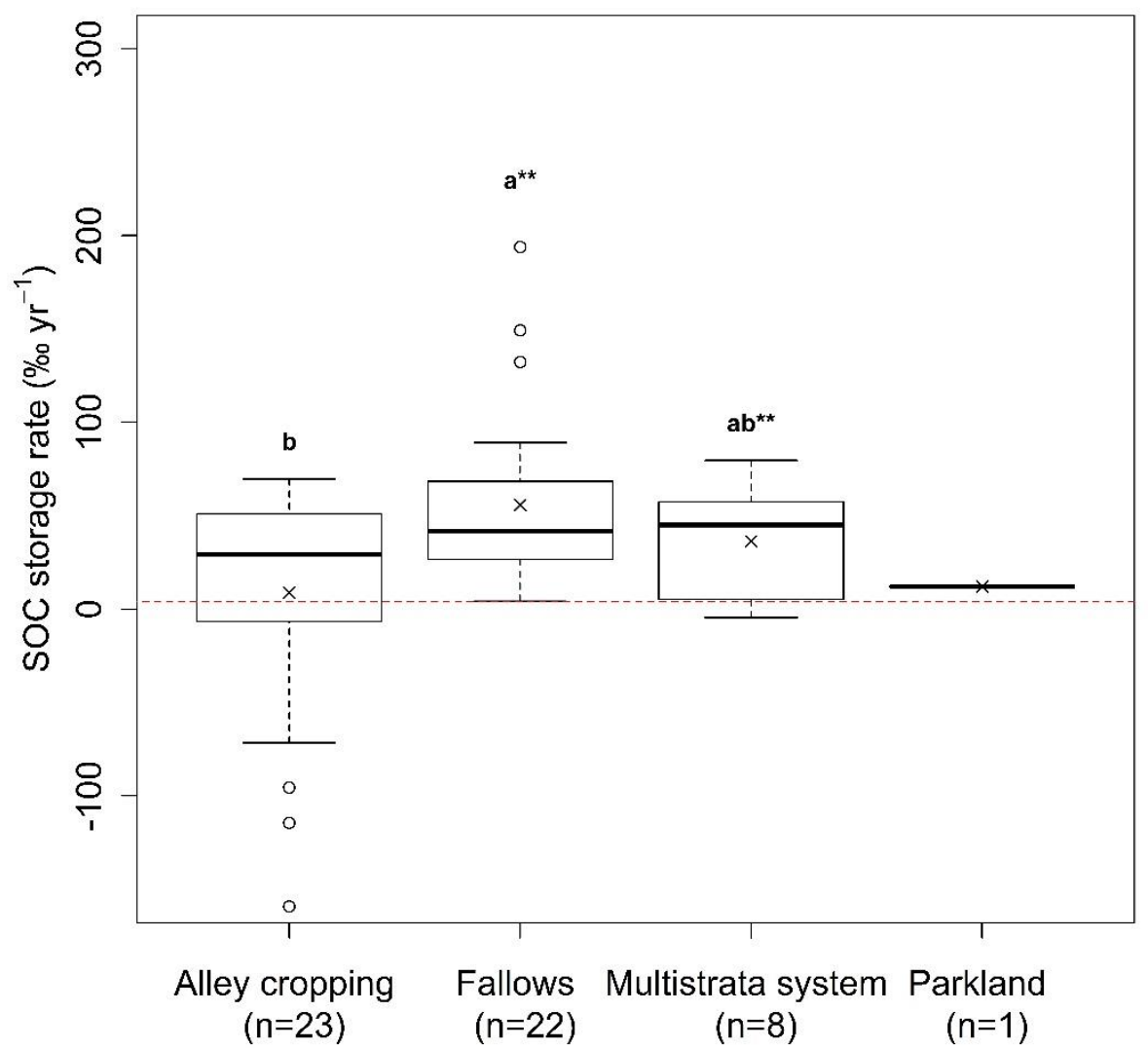

Figure S1. Comparison of SOC storage rates in the agroforestry systems taking into account all studied maximum soil depths (left) or only soil depths with a maximum of $40 \mathrm{~cm}$. Crosses represent mean SOC storage rate per type of subsystem. For each system, different letters represent significant differences between subsystems. ${ }^{*}$ represents subsystems with SOC storage rates significantly higher than $0 \%$ o $\mathrm{yr}^{-1}$ and $4 \%$ o $\mathrm{yr}^{-1}$. 